\title{
O stopniach naukowych w Polsce Ludowej. Część 2. Organizacja aspirantury naukowej i studiów doktoranckich
}

\section{Wprowadzenie}

Od pierwszych lat po zakończeniu II wojny światowej, wzorem Polski międzywojennej, utrzymano rozwiązania uznające za niższy stopień naukowy: stopień licencjata, magistra, magistra inżyniera, lekarza. I choć tego stanu rzeczy dekret z 1947 r. ${ }^{1}$ wielce nie zmienił, wprowadził istotną różnicę. Tylko stopień magistra lub równorzędny uzyskany w szkole akademickiej był niższym stopniem naukowym. W 1949 r., mimo wprowadzenia studiów dwustopniowych, nie powrócono do rozwiązań lat wcześniejszych. Niższy stopień naukowy legitymował wyłącznie dyplom ukończenia studiów drugiego stopnia lub studiów równorzędnych. Nabycie niższego stopnia naukowego w tych latach poprzedzało ukończenie pełnych studiów wyższych. Rozwiązania lat wcześniejszych nie przewidywały możliwości podjęcia studiów drugiego stopnia niekontynuujących ukończonych studiów pierwszego stopnia, jeżeli te prowadzono.

Z początkiem $1952 \mathrm{r}$. od nadawania niższych stopni naukowych absolwentom szkół wyższych odstąpiono. Od tego roku za niższe stopnie uznawano: stopień naukowy kandydata nauk, od 1958 r. stopień naukowy doktora. I choć rozwiązania z tych lat znacznie się różniły², bez wątpienia ich cechą wspólną było wdrożenie rozwiązań służących, po

${ }^{1}$ Dekret z dnia 28 X 1947 r. o organizacji nauki i szkolnictwa wyższego (Dz.U. Nr 68, poz. 415 ze zm.).

${ }^{2}$ Warunki nadawania niższych stopni naukowych w latach Polski socjalistycznej zostały omówione w: K. Wojtczak, O stopniach naukowych w Polsce Ludowej. Część 1. Niższe stopnie naukowe, "Studia Prawa Publicznego” 2016, nr 1(13), s. 27-65. 
pierwsze, rekrutacji kandydatów do pracy naukowej i badawczej oraz dydaktycznej, po drugie, zapewnieniu otoczeniu społeczno-gospodarczemu kadry o kwalifikacjach wykraczających poza wiedzę uzyskaną $\mathrm{w}$ danej dziedzinie nauki w szkole wyższej, po trzecie, zapewnieniu instytucjonalnej opieki naukowej nad przygotowaniem dysertacji na stopień naukowy, po czwarte, zrealizowaniu programu studiów, specjalnie dla tej grupy odbiorców przygotowanych i wdrożonych, po piąte, jasno określonemu statusowi osób przygotowujących rozprawę naukową i warunków ich wsparcia finansowego.

Osiągnięciu tych celów służyć miało wprowadzenie w 1952 r. $^{3}$ aspirantury naukowej, od 1958 r. studiów doktoranckich. O ile rozwiązania normujące organizację aspirantury naukowej zapewniały jej trwałość do 1958 r., mimo kilku rozwiązań nowelizujących i z uwzględnieniem przepisów przejściowych, o tyle obecność studiów doktoranckich w badanym okresie nie była wartością stałą. Zmianom podlegała nie tylko prawna legitymacja ich prowadzenia przez szkoły wyższe (także inne podmioty), ale i wymagania stawiane osobom kandydującym na studia doktoranckie, z warunkami realizacji programów tych studiów włącznie.

Bez wątpienia, prowadzenie studiów przygotowujących przyszłych adeptów do pracy naukowej przez kadrę naukową już kształcącą miało istotną wartość. Jakiej miary była to wartość i jaką drogę obrano dla jej urzeczywistnienia, jest warte poznania, a w każdym razie przypomnienia. Analiza ówczesnych rozwiązań prawnych może jednak posłużyć dalej idącemu celowi, a mianowicie ustaleniu, czy, a jeśli tak, to w jakim stopniu i zakresie, ówcześnie przyjęte rozwiązania dotyczące studiów doktoranckich można postrzegać jako odzwierciedlenie rozwiązań współczesnych. Inaczej mówiąc, czy w rozwiązaniach reform z lat 2011-2014 można dopatrywać się pewnej analogii do rozwiązań przyjętych w latach wcześniejszych, mimo odmienności reżimów prawnych, czy też z gruntu rzeczy są to wartości nieporównywalne.

\section{Aspirantura naukowa i studia doktoranckie - wprowadzenie do rozważań}

Wdrożenie ustawą z $1951 \mathrm{r}$. aspirantury naukowej niewątpliwie zapoczątkowało w latach następnych (1958-1982, 1985-1990) prowadzenie

${ }^{3}$ Ustawa z dnia 15 XII 1951 r. o szkolnictwie wyższym i o pracownikach nauki (tekst pierwotny - Dz.U. 1952 Nr 6, poz. 38). 
studiów doktoranckich. I choć te dwie drogi wyboru kariery naukowej (przyjętych w różnych latach) zmierzały do osiągnięcia tego samego celu - nadania niższego stopnia naukowego, nie były to drogi tożsame. Różnice sprowadzały się do odmienności w oznaczeniu niższych stopni naukowych (kandydat nauk, doktor), wykazów szkół wyższych (instytucji naukowych) uprawnionych do prowadzenia aspirantury naukowej i studiów doktoranckich, a także, co zrozumiałe, do celów prowadzenia studiów aspiranckich i doktoranckich, warunków ich organizacji oraz zakresu praw i obowiązków uczestników tych studiów.

Ustawa z 1951 r. przyjęła generalną zasadę, że "[a]spiranturę naukową w poszczególnych szkołach wyższych, instytutach naukowych lub w innych placówkach naukowych wprowadza Minister Szkolnictwa Wyższego w porozumieniu z właściwym ministrem, a w placówkach Polskiej Akademii Nauk - jej Prezydium"4. Przy czym rozporządzenie w sprawie organizacji aspirantury naukowej ${ }^{5}$ dodawało, że prawo jej organizowania służyć mogło tylko tym szkołom wyższym, instytutom naukowym lub innym placówkom naukowym, które posiadały wysoko kwalifikowaną kadrę pracowników nauki oraz odpowiednie wyposażenie naukowe ( $\$ 1$ ust. 2). Dla prawa kształcenia aspirantów zarazem wymagało objęcia wykazem funkcjonujących w szkołach wyższych katedr ${ }^{6}$, ich zespołów oraz instytutów, a także instytutów naukowych lub innych placówek naukowych. Wykaz ustalał minister szkolnictwa wyższego w porozumieniu z ministrami, którym podlegały szkoły wyższe (instytuty naukowe lub inne placówki naukowe) - kierując się także uzyskanym przez nie uprawnieniem do nadawania stopni naukowych. Wykaz placówek naukowych podlegających Polskiej Akademii Nauk (PAN), przy których odbywać się mogło przygotowywanie aspirantów, ustalało jej prezydium.

Tymczasem rozporządzenie w sprawie aspirantury naukowej dla pracujących zawodowo ${ }^{7}$ dla prawa jej organizowania akcenty rozłożyło

${ }^{4}$ Art. 45 ust. 3 Ustawy z dnia 15 XII 1951 r. o szkolnictwie wyższym i o pracownikach nauki, w jej pierwotnym brzmieniu oraz w brzmieniu nadanym art. 45 ust. 4 Ustawy z dnia 10 IX 1956 r. o zmianie ustawy o szkolnictwie wyższym i o pracownikach nauki (Dz.U. Nr 41, poz. 185).

${ }^{5}$ Rozporządzenie Rady Ministrów z dnia 26 IV 1952 r. w sprawie aspirantury naukowej (Dz.U. Nr 24, poz. 163).

${ }^{6}$ Warto podkreślić, że jedynie moca ustawy z dnia 15 XII 1951 r. katedra (a nie wydział) stanowiła podstawową komórkę organizacyjną szkoły wyższej (art. 6 ust. 1).

${ }^{7}$ Rozporządzenie Rady Ministrów z dnia 16 VI 1954 r. w sprawie organizacji aspirantury naukowej dla pracujących zawodowo (Dz.U. Nr 32, poz. 129). 
inaczej. W pierwszej kolejności przypisało je Polskiej Akademii Nauk, a w kolejności następnej (1) odpowiednim ministrom w im podległych szkołach wyższych ${ }^{8}$, instytutach i innych placówkach naukowych oraz (2) w instytutach naukowych, z pewnym zastrzeżeniem. Dla pierwszej grupy miarę ich uprawnień stanowiło uzyskane prawo kształcenia aspirantów, dla grupy drugiej natomiast (instytuty naukowe) - prawo do nadawania stopni naukowych. To rozróżnienie w kryteriach oceny można tłumaczyć jedynie tym, że w szkołach wyższych, instytutach i placówkach naukowych podległych właściwym ministrom oderwano odbycie aspirantury naukowej dla pracujących zawodowo od nabycia niższego stopnia naukowego (co nie znaczy, że jej ukończenie do niego nie prowadziło), czego nie zakładano w instytutach naukowych podległych właściwym ministrom.

W generalnej ocenie aspirantura prowadziła do nabycia stopnia naukowego kandydata nauk. Stopnie te mogły być nadawane w szkołach wyższych oraz w instytutach naukowych objętych odpowiednim wykazem ustalonym przez Radę Ministrów. Dla szkół wyższych ich wykaz zawierały załączniki nr 1 i 2 uchwały nr 1116 z dnia 26 listopada 1952 r. ${ }^{9}$, dla instytutów naukowych natomiast - załącznik do uchwały nr 997 z dnia 23 grudnia 1953 r. ${ }^{10}$ Obie uchwały Rady Ministrów ${ }^{11}$ zarazem zastrzegały, że szkoły wyższe, a także instytuty naukowe objęte wykazem mają prawo do nadawania stopnia kandydata nauk przy dochowaniu dwóch warunków. Pierwszy z nich sprowadzał się do zakresu nauk. Dla szkół wyższych określał je § 1 ust. 3 Rozporządzenia Rady Ministrów z dnia 26 kwietnia 1952 r. w sprawie warunków i trybu nadawania stopni

${ }^{8}$ Chodzi tu o ministrów: szkolnictwa wyższego, zdrowia, oświaty, a od 1956 r. także ministra spraw zagranicznych oraz głównego komitetu kultury fizycznej (art. 1 pkt 50 ustawy z dnia 10 IX 1956 r. o zmianie ustawy o szkołach wyższych i o pracownikach nauki).

${ }^{9}$ Uchwała nr 1116 Rady Ministrów z dnia 28 XI 1952 r. w sprawie ustalenia wykazu szkół wyższych uprawnionych do nadawania stopnia kandydata nauk (M.P. 1953 Nr 1, poz. 12 ze zm.). Wykonanie uchwały poruczono ministrowi szkolnictwa wyższego i ministrowi zdrowia.

${ }^{10}$ Uchwała nr 997 Rady Ministrów z dnia 23 XII 1953 r. w sprawie ustalenia wykazu instytutów naukowych do nadawania stopnia kandydata nauk (M.P. 1954 Nr 3, poz. 146). Wykonanie uchwały poruczono prezydium Polskiej Akademii Nauk oraz zainteresowanym ministrom.

${ }^{11} \mathrm{O}$ dalszych zmianach uchwał Rady Ministrów i kolejnych aktach prawnych zawierających stosowne wykazy szkół wyższych i instytutów naukowych uprawnionych do nadawania niższych stopni naukowych zob. K. Wojtczak, O stopniach naukowych w Polsce Ludowej..., s. 30. 
naukowych ${ }^{12}$, później rozszerzanych ${ }^{13}$. Wykaz "dyscyplin podstawowych dla poszczególnych gałęzi nauk [...]" minister szkolnictwa wyższego określił dopiero po upływie roku w załączniku do zarządzenia ${ }^{14}$. Dla instytutów naukowych uprawnionych do nadawania stopnia kandydata nauk zakres nauk był węższy, ograniczony do tych zawartych w wykazie załączonym do uchwały nr 997 z dnia 23 grudnia 1953 r. Wypełnienie warunku drugiego wymagało respektowania postanowienia, zgodnie z którym z uprawnienia do nadawania stopnia kandydata nauk mogły skorzystać szkoły wyższe, o ile temat pracy kandydackiej mieścił się w zakresie specjalności katedry (wydziału szkoły wyższej objętej wykazem), kierowanej przez pracownika nauki posiadającego tytuł profesora zwyczajnego lub profesora nadzwyczajnego. Wobec instytutów naukowych przyjęte zastrzeżenie było zbliżone - temat pracy kandydackiej miał mieścić się w ramach specjalności jednego z działów (zakładów) naukowych instytutu, którym kierował lub w którym był zatrudniony pracownik nauki posiadający tytuł profesora zwyczajnego lub profesora nadzwyczajnego.

W odniesieniu do studiów doktoranckich kwestia ta wyglądała zgoła odmiennie. Ustawa z dnia 5 września 1958 r. o szkołach wyższych ${ }^{15}$, wprowadzając je, stanowiła, że „[o]soba, która ukończyła studia w szkole wyższej, może być przyjęta na studia doktoranckie, których celem jest uzyskanie stopnia naukowego doktora", oraz że przepisy dotyczące studentów stosuje się odpowiednio do doktorantów, jeżeli przepisy wykonawcze ich dotyczące nie postanowią inaczej. To odniesienie prawnej regulacji dotyczącej studentów do doktorantów skutkowało również tym, że rekrutację na studia doktoranckie i ich odbywanie podporządkowano kierunkom studiów.

Ustawą z 1958 r. odstąpiono od statusu katedry jako podstawowej jednostki organizacyjnej szkoły wyższej. Status ten przywrócono wydziałom szkół wyższych, zarazem powierzając im prawo prowadzenia studiów doktoranckich i obejmując je wykazem (ze wskazaniem szkoły wyższej $)^{16}$. Od 1965 r. w związku z wejściem w życie ustawy o stopniach

${ }^{12}$ Dz.U. Nr 24, poz. 164 ze zm.

${ }^{13}$ Szerzej zob. K. Wojtczak, O stopniach naukowych w Polsce Ludowej..., s. 35.

${ }^{14}$ Załącznik do Zarządzenia Ministra Szkolnictwa Wyższego z dnia 28 V 1953 r. w sprawie wykazu dyscyplin podstawowych dla poszczególnych gałęzi nauki i egzaminów kandydackich składanych w szkołach wyższych podległych Ministrowi Szkolnictwa Wyższego (M.P. Nr 55, poz. 698).

${ }^{15}$ Dz.U. Nr 68, poz. 336.

${ }^{16}$ Art. 8 ust. 2 ustawy z dnia 5 XI 1958 r. o szkołach wyższych, a także $\S 1$ ust. 2 Rozporządzenia Ministrów Szkolnictwa Wyższego, Zdrowia i Opieki Społecznej, Oświaty, 
i tytułach naukowych ${ }^{17}$ ustawę z 1958 r. o szkołach wyższych w zakresie dotyczącym studiów doktoranckich znowelizowano dwukrotnie. W $1965 \mathrm{r}^{18}{ }^{2}$ mieniono treść art. 11 ust. $1 \mathrm{w}$ ten sposób, że w szkołach wyższych w ramach wydziału mogły być prowadzone także studia doktoranckie ${ }^{19}$, czego nie zawierał tekst pierwotny ustawy z 1958 r., chociaż ten w art. 48 ust. 3 wyraźnie formułował prawo dostępu absolwenta szkoły wyższej do studiów doktoranckich. Natomiast w noweli z 1968 r. ${ }^{20}$ przyjęto tylko tyle, że szkoły wyższe mogą prowadzić m.in. studia doktoranckie ${ }^{21}$. Z kolei ustawa o szkolnictwie wyższym z dnia

Spraw Zagranicznych oraz Przewodniczącego Głównego Komitetu Kultury Fizycznej i Turystyki z dnia 30 IV 1960 r. w sprawie zasad odbywania studiów doktoranckich w szkołach wyższych, praw i obowiązków doktorantów oraz wysokości stypendiów dla doktorantów (Dz.U. Nr 28, poz. 159).

${ }^{17}$ Ustawa z dnia 31 III 1965 r. o stopniach naukowych i tytułach naukowych (Dz.U. Nr 14, poz. 101 ze zm.).

${ }^{18}$ Ustawa z dnia 31 III 1965 r. o zmianie ustawy o szkołach wyższych (Dz.U. Nr 14, poz. 98).

${ }^{19}$ Podobnej treści postanowienie wprowadzono w ustawie z 1965 r. o stopniach naukowych i tytułach naukowych. Artykuł 7 ust. 1 tej ustawy brzmiał: „W ramach wydziałów i innych jednostek uprawnionych do nadawania stopni naukowych można utworzyć studia doktoranckie".

${ }^{20}$ Ustawa z dnia 20 XII 1968 r. o zmianie ustawy o szkolnictwie wyższym (Dz.U. Nr 46, poz. 334).

${ }^{21}$ Rozporządzenie Ministra Oświaty i Szkolnictwa Wyższego z dnia 15 II 1968 r. w sprawie zasad odbywania studiów doktoranckich (Dz.U. Nr 6, poz. 38 ze zm.) prawo tworzenia tych studiów zarezerwowało wyłącznie dla: ministra oświaty i szkolnictwa wyższego w porozumieniu z sekretarzem naukowym PAN - w odniesieniu do szkół wyższych i samodzielnych placówek naukowo-dydaktycznych podległych temuż ministrowi; właściwego ministra $\mathrm{w}$ porozumieniu $\mathrm{z}$ ministrem oświaty i szkolnictwa wyższego oraz z sekretarzem naukowym PAN - w odniesieniu do szkół wyższych i samodzielnych placówek typu naukowo-dydaktycznego podległych innemu ministrowi oraz w instytutach naukowo-badawczych; sekretarzowi naukowemu PAN w porozumieniu z ministrem oświaty i szkolnictwa wyższego - w placówkach naukowych PAN. Niemalże identycznej treści rozwiązanie w zakresie określenia podmiotów upoważnionych do tworzenia studiów doktoranckich przyjęło Rozporządzenie Ministra Nauki, Szkolnictwa Wyższego i Techniki z dnia 17 XII 1976 r. w sprawie studiów doktoranckich (Dz.U. Nr 41, poz. 243) oraz Rozporządzenie Ministra Nauki i Szkolnictwa Wyższego z dnia 10 VII 1986 r. w sprawie studiów doktoranckich i stypendiów naukowych (Dz.U. Nr 28, poz. 138). Zgodnie z \& 1 rozporządzenia z 1986 r. studia doktoranckie mogły być "tworzone w jednostkach organizacyjnych szkół wyższych, placówkach naukowych Polskiej Akademii Nauk, instytutach naukowo-badawczych lub samodzielnych placówkach typu naukowo-dydaktycznego, posiadających uprawnienia do nadawania stopnia naukowego doktora habilitowanego". Różnice sprowadzały się zatem do zmiany w nazwie urzędu ministra właściwego w sprawach szkolnictwa wyższego. W sprawach zmian nazwy tego urzędu i zakresu działania na przestrzeni lat 1920-1990 zob. K. Wojtczak, Prawne determinanty 
4 maja $1982 \mathrm{r}^{22} \mathrm{w}$ brzmieniu pierwotnym normowała kwestię studiów doktoranckich jedynie w zakresie przewidzianym art. 223 zachowującym prawa słuchaczy tych studiów do ich ukończenia według przepisów dotychczasowych. Jej nowelizacja w $1985 \mathrm{r}^{23}$ stanowiła natomiast, co wtedy było niezwykle ważne, ale i wyraźnie zaostrzające dotychczasowe w tym zakresie wymagania, że studia doktoranckie prowadzić mogły wyłącznie jednostki organizacyjne szkół wyższych uprawnione do nadawania stopnia naukowego doktora habilitowanego.

Ta szczupłość ustawowych regulacji prawa o szkolnictwie wyższym odnoszona do studiów doktoranckich, z założenia zakończonych nabyciem stopnia naukowego doktora, nie dowodziła niestaranności ustawodawcy. Była wynikiem przyjęcia nowej koncepcji regulacji - oddzielenia spraw szkolnictwa wyższego od nadawania stopni i tytułów naukowych. Od tej koncepcji w latach następnych, aż po rozwiązania aktualnie obowiązujące, nie odstąpiono, i słusznie.

Począwszy od 1958 r., granice czasowe wprowadzanych w życie ustaw o szkołach wyższych/szkolnictwie wyższym oraz ustawy z $1965 \mathrm{r}$. o stopniach i tytułach naukowych (wraz z ich zmianami) nie odpowiadały zakresom czasowym obowiązywania przepisów wykonawczych normujących zasady odbywania studiów doktoranckich. Wydane na podstawie pierwszej ustawy rozporządzenie z 1960 r. dotyczące tych studiów ${ }^{24}$ uchylono w 1968 r. rozporządzeniem ministra oświaty i szkolnictwa wyższego ${ }^{25}$ już wydanym na podstawie ustawy z $1965 \mathrm{r}$. o stopniach i tytułach naukowych, które w latach następnych zastapiono dwoma kolejnymi rozporządzeniami z $1976^{26}$ oraz 1986 r. ${ }^{27}$ Prowa-

procesu kształcenia w szkołach wyższych w latach 1920-1990 (Część I), „Studia Prawa Publicznego" 2013, nr 4, s. 68-72.

${ }^{22}$ Ustawa z dnia 4 V 1982 r. o szkolnictwie wyższym (Dz.U. Nr 14, poz. 113 ze zm.).

${ }^{23}$ Ustawa z dnia 25 VII 1985 r. o zmianie ustawy o szkolnictwie wyższym (Dz.U. Nr 36, poz. 167).

${ }^{24}$ Rozporządzenie Ministrów Szkolnictwa Wyższego, Zdrowia i Opieki Społecznej, Oświaty, Spraw Zagranicznych oraz Przewodniczącego Głównego Komitetu Kultury Fizycznej i Turystyki z dnia 30 IV 1960 r. w sprawie zasad odbywania studiów doktoranckich w szkołach wyższych, praw i obowiązków doktorantów oraz wysokości stypendiów dla doktorantów.

${ }^{25}$ Rozporządzenie Ministra Oświaty i Szkolnictwa Wyższego z dnia 15 II 1968 r. w sprawie zasad odbywania studiów doktoranckich.

${ }^{26}$ Rozporządzenie Ministra Nauki, Szkolnictwa Wyższego i Techniki z dnia 17 XII 1976 r. w sprawie studiów doktoranckich.

${ }^{27}$ Rozporządzenie Ministra Nauki i Szkolnictwa Wyższego z dnia 10 VII 1986 r. w sprawie studiów doktoranckich i stypendiów naukowych. Rozporządzenie to 
dzenie studiów doktoranckich dla pracujących przewidywało dopiero rozporządzenie z $1968 \mathrm{r}$.

\section{Aspirantura naukowa - warunki dostępu i organizacja}

Początkowo (od 1952 r.) prowadzenie aspirantury naukowej przewidziano wyłącznie dla osób niezatrudnionych, od $1954 \mathrm{r}$. formułę aspirantury rozszerzono, tworząc warunki jej odbywania także przez osoby zatrudnione poza szkołą wyższą. Ta dwutorowość w odbywaniu studiów aspiranckich miała uzasadnienie w celach ówcześnie wyznaczonych do ich osiągnięcia. Zakładano, że dla pierwszej grupy aspirantura ma być formą kształcenia naukowego i naukowo-pedagogicznego, z wykluczeniem łączenia odbywania aspirantury $\mathrm{z}$ wykonywaniem pracy zawodowej $^{28}$. W efekcie zakładano zatem kształcenie prowadzące do umocnienia potencjału przyszłej kadry naukowej i naukowo-dydaktycznej. Założenie to wzmacniało wymagane od aspiranta zobowiązanie, że po uzyskaniu stopnia kandydata nauk przez okres przynajmniej trzech lat pracować będzie na wyznaczonym mu przez właściwego ministra (prezydium PAN) stanowisku pracownika nauki ( $\$ 3$ ust. 3 rozporządzenia z 1952 r. w sprawie aspirantury naukowej).

Dla osób z drugiej grupy, pracujących zawodowo poza szkołami wyższymi lub instytutami (placówkami) naukowymi uprawnionymi do prowadzenia aspirantury organizowanej przez PAN oraz ministerstwa w podległych sobie szkołach wyższych i instytutach naukowych, aspirantura stanowić miała formę naukowego doskonalenia zawodowego w podstawowych dziedzinach gospodarki i kultury narodowej. W odróżnieniu od aspirantury pierwszej grupy (bez możliwości jej łączenia z pracą zawodową) aspirantura prowadzona dla osób pracujących zawodowo tym samym zapoczątkowała model "uzawodowionej”

obowiązywało do 1 IV 1990 r., tj. do czasu wejścia w życie Rozporządzenia Ministra Edukacji Narodowej z dnia 10 VI 1991 r. w sprawie studiów doktoranckich i stypendiów naukowych (Dz.U. Nr 58, poz. 249), wydanego już na podstawie Ustawy z dnia 12 IX 1990 r. o tytule naukowym i stopniach naukowych (Dz.U. Nr 65, poz. 386).

${ }^{28}$ Równocześnie dopuszczenie do odbywania aspirantury wiązano z obowiązkiem każdego urzędu lub innego zakładu pracy rozwiązania stosunku służbowego lub stosunku pracy z osobami do niej dopuszczonymi z dniem określonym w decyzji dla rozpoczęcia aspirantury. Decyzja ta miała być doręczona pracodawcy przynajmniej na trzydzieści dni przed terminem określonym w decyzji dla rozpoczęcia aspirantury ( $\$ 4$ ust. 4 rozporządzenia w sprawie organizacji aspirantury). 
aspirantury naukowej. Odpowiednio do tak postrzeganej istoty tej formy aspirantury jej absolwent był obowiązany pracować przynajmniej trzy lata na stanowisku wyznaczonym przez władzę naczelną zatrudniającej go instytucji. Nie był to jednak warunek absolutny. Prezydium PAN bądź właściwy minister mógł bowiem w porozumieniu z ową władzą naczelną instytucji skierować aspiranta do pracy naukowej w szkole wyższej, instytucie naukowym lub innej placówce naukowej ( 119 rozporządzenia z 1954 r. w sprawie aspirantury dla pracujących zawodowo).

\subsection{Rekrutacja na studia aspiranckie}

Aspirantura naukowa nie była dostępna dla wszystkich. Ograniczenia w tym zakresie determinowały trzy przesłanki: warunki wymagane od kandydata i ich ocena oraz przyjęcie na aspiranturę naukową. O dopuszczenie do niej mogły się ubiegać osoby, które:

1. wykazały zamiłowanie i uzdolnienia do pracy naukowej i naukowo-pedagogicznej, a w przypadku aspirantury dla pracujących - zamiłowanie do pracy naukowo-badawczej związanej z pracą zawodowa, wykonywaną przez okres co najmniej dwóch lat po ukończeniu studiów wyższych, w zakresie specjalności mającej stanowić przedmiot ich studiów aspiranckich;

2. ukończyły studia wyższe drugiego stopnia lub równorzędne, względnie posiadały stopień magistra lub lekarza;

3. złożyły przed komisją egzaminy ${ }^{29}$ : ze znajomości podstaw marksizmu-leninizmu, języka rosyjskiego oraz obranej dyscypliny naukowej, w zakresie objętym programem studiów drugiego stopnia lub równorzędnych ${ }^{30}$. Komisje egzaminacyjne powoływał rektor szkoły wyższej (kierownik instytutu naukowego lub innej placówki naukowej),

${ }^{29}$ Dla obu trybów aspirantury składy komisji egzaminacyjnych nieco się różniły. Dla aspirantów z pierwszej grupy skład komisji egzaminacyjnych tworzyli: dziekan lub prodziekan właściwego wydziału (kierownik instytutu naukowego lub placówki naukowej albo jego zastępca), jako przewodniczący, oraz dwaj samodzielni pracownicy nauki, jako członkowie. Z kolei w skład komisji egzaminacyjnych dla osób ubiegających się o dopuszczenie do aspirantury naukowej dla pracujących zawodowo wchodzili: dziekan wydziału (kierownik instytutu naukowego lub innej placówki naukowej), jako przewodniczący, oraz trzech specjalistów w zakresie dyscyplin naukowych objętych programem egzaminu, w miarę możliwości powoływani spośród samodzielnych pracowników nauki, jako członkowie komisji.

${ }^{30}$ Por. $\S 3$ ust. 1 rozporządzenia z 1952 r. w sprawie organizacji aspirantury naukowej. 
a w odniesieniu do aspirantury dla osób pracujących zawodowo - rektor na wniosek dziekana właściwego wydziału (kierownik instytutu naukowego albo innej placówki naukowej).

Decyzja o dopuszczeniu do odbywania aspirantury naukowej, przy ograniczeniu ogólnej liczby aspirantów ${ }^{31}$, leżała w gestii ministra, któremu podlegały uprawnione szkoły wyższe (instytuty lub placówki naukowe), a w przypadku placówek PAN - w gestii jej prezydium. Tymczasem o dopuszczeniu do aspirantury naukowej dla osób pracujących zawodowo, po uprzedniej rekrutacji przeprowadzonej przez te resorty, których wnioski uwzględniono przy ogólnej liczbie aspirantów, decydowało prezydium Polskiej Akademii Nauk bądź właściwy minister, stosownie do tego, który z tych podmiotów był organizującym aspiranturę w szkołach wyższych bądź instytutach naukowych - posiadających prawo nadawania stopni naukowych.

Dla obu grup aspirantów prawodawca wprawdzie przewidywał obowiązek wyznaczenia przez rektora szkoły wyższej na wniosek dziekana (kierownika instytutu naukowego lub innej placówki naukowej) kierującego pracą naukową aspiranta - samodzielnego pracownika nauki odpowiedzialnego za kierunek i należytą kontrolę przebiegu studiów aspiranckich, nieco inaczej jednak ukształtował warunki i przebieg aspirantury.

\subsection{Warunki i przebieg aspirantury}

W odniesieniu do pierwszej kategorii aspirantów indywidualny plan pracy aspiranta naukowego (ustalony zgodnie z przyjętą procedurą ${ }^{32}$ )

${ }^{31}$ Ustalanie ogólnej liczby aspirantów naukowych, z uwzględnieniem poszczególnych dyscyplin naukowych, należało do Rady Ministrów, a w odniesieniu do aspirantury naukowej dla pracujących zawodowo - do Państwowej Komisji Planowania Gospodarczego w porozumieniu z PAN na podstawie wniosków zainteresowanych resortów ( $\$ 2$ ust. 1 rozporządzenia Rady Ministrów z dnia 20 IV 1952 r., § 4 rozporządzenia Rady Ministrów z dnia 16 VI 1954 r.).

${ }^{32} \mathrm{Na}$ wniosek samodzielnego pracownika nauki kierującego pracą aspiranta jego indywidualny plan pracy ustalali, według właściwości: kierownik katedry (kierownik zespołu katedr) po wysłuchaniu opinii zebrania wszystkich członków katedry (zebrania naukowego), kierownik instytutu szkoły wyższej (instytutu naukowo-badawczego) po wysłuchaniu opinii rady naukowej (zespołu pracowników nauki). Kierownik katedry (zespołu katedr) lub instytutu szkoły wyższej referował indywidualny plan pracy aspiranta radzie wydziałowej oraz przedkładał go rektorowi. Następnie szkoła wyższa (instytut naukowy lub inna placówka naukowa) była obowiązana indywidualne plany aspirantów 
obejmował: studia nad materializmem dialektycznym i historycznym (według programu ustalonego przez ministra szkolnictwa wyższego); studia $\mathrm{w}$ zakresie dyscypliny naukowej obranej przez aspiranta; zapoznanie się z najnowszą literaturą dotyczącą tej dyscypliny naukowej oraz dyscyplin pokrewnych; opanowanie dwóch języków obcych, w tym języka rosyjskiego, w zakresie potrzebnym dla pracy naukowo-badawczej. Aspiranta obowiązano do ścisłego wykonywania planu swojej pracy, a ponadto do uczestnictwa w wykładach, konsultacjach, zajęciach praktycznych i seminariach; pracy dydaktycznej w szkołach wyższych w wymiarze nieprzekraczającym sześciu godzin tygodniowo; złożenia egzaminów kandydackich; przedstawienia samodzielnemu pracownikowi nauki do zatwierdzenia tematu pracy kandydackiej wraz z projektem jej planu w ciągu trzech miesięcy od rozpoczęcia aspirantury $^{33}$, a w terminie trzech miesięcy przed jej zakończeniem - złożenia pracy kandydackiej. Termin ten mógł być przedłużony. Tymczasem indywidualny plan pracy aspirantów $z$ drugiej grupy (łączących aspiranturę z pracą zawodową ${ }^{34}$ ) ustalał program studiów aspiranckich wraz z terminarzem czterech egzaminów z: materializmu dialektycznego i historycznego, dyscypliny specjalnej odpowiadającej tematowi pracy kandydackiej, dyscypliny podstawowej dla danej dziedziny wiedzy oraz dwóch języków obcych, w tym języka rosyjskiego ${ }^{35}$; ponadto wymagał określenia tematu pracy kandydackiej wraz ze szkicem jej planu, z zastrzeżeniem ścisłego powiązania tematu pracy z wykonywaną przez

przesłać do wiadomości właściwemu ministrowi bądź prezydium w odniesieniu do jednostek podlegających PAN ( 8 rozporządzenia Rady Ministrów z 1952 r. w sprawie organizacji aspirantury naukowej).

${ }^{33}$ Temat pracy kandydackiej aspiranta naukowego wymagał ujęcia $\mathrm{w}$ planie pracy katedry (zespołu katedr, instytutu naukowego lub innej placówki naukowej), w której dopuszczono prowadzenie aspirantury.

${ }^{34} \mathrm{~W}$ przypadku tej grupy aspirantów indywidualny plan pracy ustalał w porozumieniu z aspirantem samodzielny pracownik nauki kierujący jego studiami, a zatwierdzał kierownik instytutu naukowego lub innej placówki naukowej po zasięgnięciu opinii rady naukowej instytutu lub placówki. Natomiast w razie odbywania aspirantury naukowej w szkołach wyższych zastosowanie znajdowały przepisy odnoszone w tym zakresie do aspirantów naukowych niełączących ich odbywania z pracą zawodową ( $\$ 11$ rozporządzenia Rady Ministrów z 1954 r. w sprawie organizacji aspirantury naukowej dla pracujących zawodowo).

${ }^{35} \mathrm{~W}$ jakim roku studiów aspirant był obowiązany do złożenia egzaminów objętych ich programem, szczegółowo określał Załącznik do Zarządzenia Ministra Szkolnictwa Wyższego z dnia 2 IX 1955 r. w sprawie regulaminu studiów aspiranckich dla osób pracujących zawodowo i odbywających aspiranturę w szkołach wyższych podległych Ministrowi Szkolnictwa Wyższego (M.P. Nr 83, poz. 991). 
aspiranta pracą zawodowa, i to uzgodnionego z instytucją zatrudniająca go. Zdyscyplinowaniu poczynań aspiranta pracującego zawodowo miało służyć także jego zobowiązanie do składania comiesięcznych sprawozdań z przebiegu studiów, odbywania przynajmniej raz na trzy miesiące konsultacji z samodzielnym pracownikiem nauki kierującym jego studiami, uczestniczenia w konferencjach, seminariach bądź innych zajęciach istotnych dla należytej realizacji indywidualnego planu pracy, poddania się osobiście przynajmniej raz w roku ocenie komisji sprawdzającej postępy aspiranta z zakresu wszystkich dyscyplin naukowych objętych indywidualnym planem pracy, a na pół roku przed zakończeniem aspirantury przedstawienia pracy kandydackiej.

Wyznaczonym aspirantowi obowiązkom odpowiadały określone prawem zachowania osoby sprawującej indywidualną opiekę nad aspirantem, kierowników katedr lub instytutów oraz dziekana i rektora szkoły wyższej (kierownika instytutu naukowego lub innej placówki naukowej).

Samodzielny pracownik nauki przede wszystkim odpowiadał za kierunek i wyniki pracy przydzielonego mu aspiranta. $Z$ tego tytułu występował $\mathrm{z}$ wnioskiem o ustalenie indywidualnego planu pracy aspiranta (zatwierdzenie planu pracy aspiranta naukowego pracującego zawodowo). Jeśli indywidualny plan pracy aspiranta (aspirantury z pierwszej grupy) nie mógł być w całości wykonany w ramach katedry (zespołu katedr, instytutu lub innej placówki naukowej), na samodzielnym pracowniku kierującym jego pracą spoczywał obowiązek zorganizowania, w porozumieniu z właściwym rektorem szkoły wyższej (kierownikiem instytutu naukowego lub innej placówki naukowej), zajęć uzupełniających. W odniesieniu do aspirantury dla pracujących zawodowo (i tylko w odniesieniu do tej grupy) samodzielny pracownik nauki sprawujący opiekę naukową był obowiązany, poza konsultacjami, do udzielania aspirantowi $\mathrm{w}$ razie potrzeby - pisemnych wyjaśnień i informacji oraz, co jest istotne, do odwiedzenia przynajmniej raz $\mathrm{w}$ roku zakładu pracy zatrudniającego aspiranta $w$ celu zapoznania się $z$ warsztatem i systemem jego pracy zawodowej, w powiązaniu z którą przygotowywał on rozprawę kandydacką.

Do sprawującego opiekę naukową nad aspirantem należało ponadto systematyczne informowanie rektora szkoły wyższej (kierownika instytutu lub innej placówki naukowej), a w odniesieniu do aspirantów łączących aspiranturę z pracą zawodową - dziekana wydziału, o wynikach pracy aspiranta oraz przedkładanie co najmniej dwa razy w roku sprawozdań $\mathrm{z}$ wyników jego pracy. $\mathrm{W}$ odniesieniu do pierwszej $\mathrm{z}$ form aspirantury sprawozdania $\mathrm{z}$ tytułu kierowania pracą aspiranta 
przedkładane były na zebraniu członków katedry (zebraniu naukowym - zespołu katedr, rady naukowej instytutu naukowego, zespołu pracowników nauki instytutu naukowo-badawczego), w odniesieniu zaś do grupy drugiej - prezydium Polskiej Akademii Nauk lub ministerstwu prowadzącemu aspiranturę.

Dziekana wydziału zobowiązano do omawiania na posiedzeniu rady wydziałowej wyników pracy aspiranta naukowego co najmniej raz $\mathrm{w}$ roku. Innej treści postanowienie przyjęło rozporządzenie w sprawie aspirantury naukowej dla pracujących zawodowo. Tu rada wydziałowa szkoły wyższej lub rada naukowa instytutu naukowego wprawdzie także miała oceniać raz do roku wyniki pracy aspiranta, ale po uprzednim ich sprawdzeniu przez komisję powołaną przez rektora na wniosek dziekana (§ 12 ust. 2 pkt 4). Zgodnie zaś z regulaminem studiów aspiranckich dla pracujących zawodowo w szkołach wyższych (podległych ministrowi szkolnictwa wyższego) rada wydziałowa mogła zlecić przeprowadzenie postępowania atestacyjnego ( $\mathrm{z}$ końcem każdego roku aspirantury) specjalnie powołanej przez siebie komisji ${ }^{36}$. Postępowanie atestacyjne obejmowało: sprawozdanie kierownika naukowego z przebiegu studiów aspiranckich w ciągu ostatniego roku, wyjaśnienia aspiranta związane z przebiegiem tych studiów, przeprowadzenie $z$ aspirantem dyskusji dotyczącej całokształtu dotychczasowej jego praktyki oraz podjęcie decyzji w sprawie dopuszczenia aspiranta do dalszych stadiów i udzielenia mu zaleceń co do jego pracy w następnym roku aspirantury bądź powzięcie wniosku o jej cofnięciu. Zatwierdzona przez prorektora do spraw nauki atestacja (wraz z odpisami: sprawozdania kierownika naukowego oraz protokołu z posiedzenia rady wydziałowej bądź komisji atestacyjnej) wymagała przesłania ministrowi szkolnictwa wyższego.

Rektor szkoły wyższej (kierownik instytutu naukowego, placówki naukowej) sporządzał roczne sprawozdanie z przebiegu pracy aspirantów i przedkładał je właściwemu ministrowi (prezydium PAN) ${ }^{37}$.

\footnotetext{
${ }^{36}$ Jej skład tworzyli: prorektor do spraw nauki w danej szkole wyższej, kierownik naukowy aspiranta oraz dwóch samodzielnych pracowników nauki reprezentujących nauki pokrewne w stosunku do dyscyplin będących przedmiotem studiów aspiranta. W posiedzeniu komisji (także rady wydziałowej przeprowadzającej atestację w przypadku niepowołania specjalnej komisji) uczestniczył zaproszony przez szkołę wyższą przedstawiciel zakładu zatrudniającego aspiranta (pkt 9 regulaminu studiów aspiranckich dla osób pracujących zawodowo, odbywających aspiranturę w szkołach wyższych podległych ministrowi szkolnictwa wyższego).

${ }^{37}$ Choć dzisiaj można obligatoryjne ówcześnie rozwiązania traktować jako nazbyt scentralizowane, a przez to lepiej ówczesnej władzy służące w sprawowaniu stałej
} 
Czas trwania aspirantury pierwotnie (od dnia wejścia w życie ustawy z 1951 r.) wyznaczono na okres dwóch lat, od połowy 1953 r. termin ten przedłużono do lat trzech ${ }^{38}$. Dla odbywania aspirantury dla osób pracujących zawodowo przewidziano okres nie dłuższy niż cztery lata, z możliwością jego przedłużenia przez PAN bądź właściwego ministra do lat pięciu ${ }^{39}$. Od 1955 r. okres czteroletniej aspirantury mógł być także skrócony ${ }^{40}$. O przedłużeniu aspirantury decydował minister szkolnictwa wyższego.

Przed upływem terminu ukończenia aspirantury naukowej aspirant naruszający postanowienia rozporządzenia normującego jej przebieg (1952) bądź uchybiający swym zachowaniem godności pracownika nauki mógł być skreślony $\mathbf{z}$ listy aspirantów naukowych. O skreśleniu z listy orzekał właściwy minister (prezydium PAN) na wniosek rektora szkoły wyższej (kierownika instytutu naukowego lub innej placówki naukowej), przy której osoba odbywała aspiranturę. W odniesieniu zaś do drugiej grupy aspirantów (łączących aspiranturę z pracą zawodową) rozporządzenie z 1954 r. podstawę skreślenia z listy aspirantów formułowało nieco szerzej. Wśród przesłanek stanowiących podstawę skreślenia wymieniało: stwierdzenie przez radę wydziałową szkoły wyższej (radę naukową instytutu lub innej placówki naukowej) wyraźnych uchybień w studiach aspiranckich; naruszenie przepisów dotyczących aspirantury naukowej dla pracujących zawodowo; uchybienie w swym zachowaniu godności aspiranta. Były to przesłanki rozłączne. Skreślenie z listy aspirantów nie podlegało ochronie prawnej.

\subsection{Wsparcie - finansowe i socjalne aspirantów naukowych}

Odpowiednio do zróżnicowania formuły aspirantury naukowej (dla niepracujących - pracujących zawodowo) i stawianych z tego tytułu aspirantom wymagań, prawodawca nieco odmiennie ukształtował

i wnikliwej oceny kształcenia kadry naukowej zgodnie z zakładanymi wartościami społeczeństwa socjalistycznego, ich niewątpliwym walorem było zdecydowanie jasne określenie obowiązków obu stron postępowania (promotora - aspiranta) oraz władz uczelni.

${ }^{38}$ Por. § 1 Rozporządzenia Rady Ministrów z dnia 20 VI 1953 r., zmieniającego rozporządzenie z dnia 26 IV 1952 r. w sprawie organizacji aspirantury (Dz.U. Nr 35, poz. 146).

${ }^{39}$ Por. § 9 rozporządzenia Rady Ministrów z dnia 16 VI 1954 r. w sprawie organizacji aspirantury naukowej dla pracujących zawodowo.

${ }^{40}$ Zgodnie z pkt 1 regulaminu studiów aspiranckich dla osób pracujących zawodowo odbywających aspiranturę w szkołach wyższych podległych ministrowi szkolnictwa wyższego. 
warunki ich wsparcia w sferze spraw socjalnych i finansowych. Aspirant naukowy z grupy pierwszej nie mógł pracować zawodowo, z wyłączeniem pracy pedagogicznej w szkolnictwie wyższym w wymiarze do sześciu godzin tygodniowo lub pracy w charakterze pracownika nauki w instytucie naukowo-badawczym w wymiarze pół etatu, przy zaszeregowaniu nie wyższym niż szósta grupa uposażenia pracowników nauki w każdym przypadku odpowiednio za zgodą właściwego ministra lub prezydium PAN. W razie decyzji o dopuszczeniu do aspirantury osoby wcześniej zatrudnionej zawodowo wszelkie urzędy i inne zakłady pracy zobowiązano do rozwiązania $z$ nią stosunku służbowego lub stosunku pracy $\mathrm{z}$ dniem określonym $\mathrm{w}$ decyzji dla rozpoczęcia aspirantury, doręczanej pracodawcy na trzydzieści dni przed terminem w decyzji tej wskazanym. Aspirant naukowy otrzymywał natomiast stypendium w wysokości określonej uchwałą Prezydium Rządu, a ponadto korzystał z prawa do corocznego trzydziestodniowego urlopu wypoczynkowego. Przysługiwały mu także przewidziane dla pracowników państwowych ulgi przy przejazdach kolejowych. On i jego rodzina mogli korzystać ze świadczeń zakładów uspołecznionych służby zdrowia. Okres trwania aspirantury naukowej doliczano do okresu zatrudnienia stanowiącego podstawę przyznania zaopatrzenia na wypadek niezdolności do pracy lub na starość (emerytalnego).

Tymczasem aspirantura dla pracujących zawodowo wymagała ustanowienia nieco innych standardów. Wobec ich zawodowej czynności instytucję zatrudniającą aspiranta zobowiązano do udzielania mu, na jego wniosek zatwierdzony przez samodzielnego pracownika nauki kierującego pracą naukowa, niezależnie od urlopu wypoczynkowego (w łącznym wymiarze dwudziestu ośmiu dni rocznie) płatnego zwolnienia od pracy służącego usprawiedliwieniu udziału w konsultacjach, seminariach, egzaminach kontrolnych i innych zajęciach ${ }^{41}$ oraz przygotowaniu się do tych zajęć. Uprawnienie to powiększono o kolejne dwadzieścia osiem dni płatnego zwolnienia od pracy w roku kalendarzowym, w którym aspirant złożył pracę kandydacką. Aspirantowi mógł być przyznany zasiłek na zakup pomocy naukowych. Dla zapewnienia stabilności i skuteczności odbywanej aspirantury niezwykle ważne było także zapewnienie aspirantom prawnej ochrony. Temu służyło, po pierwsze, odstąpienie przez pracodawcę od zatrudniania aspiranta w godzinach

${ }^{41} \mathrm{Z}$ tego tytułu aspirantowi służyły diety oraz zwrot kosztów podróży według zasad przyjętych dla pracowników państwowych (§ 18 ust. 1 rozporządzenia z $1954 \mathrm{r}$. w sprawie aspirantury dla pracujących zawodowo). 
nadliczbowych oraz zlecania mu prac dodatkowych, z jednoczesnym zakazem przyjmowania przez aspiranta prac zleconych i ubocznych zajęć zarobkowych, po drugie, ochrona zatrudnienia. W okresie odbywania aspirantury stosunek służbowy (stosunek pracy) z aspirantem mógł być wprawdzie rozwiązany, lecz tylko przez władzę naczelną instytucji zatrudniającej aspiranta, i to działającą w porozumieniu z prezydium PAN bądź właściwym ministrem.

\section{Studia doktoranckie - cel oraz dostęp do studiów doktoranckich i ich organizacja}

Podstawę tworzenia studiów doktoranckich wprawdzie dała ustawa z 1958 r. o szkołach wyższych ${ }^{42}$, jednak cel ich prowadzenia i odbywania oraz warunki przyjęcia na studia po raz pierwszy określono dopiero półtora roku później, w dniu 30 kwietnia 1960 r. ${ }^{43}$ Odstępowano od nich częściowo w latach następnych, zwykle przez doprecyzowanie lub zmianę w kolejnych aktach wykonawczych wydanych na podstawie ustawy z 1965 r. o stopniach naukowych i tytułach naukowych, celu studiów doktoranckich oraz zasad i warunków ich organizacji i przebiegu.

Początkowo studia doktoranckie, podobnie jak aspiranturę naukowa, zarezerwowano wyłącznie dla osób niełączących ich z zatrudnieniem. W odróżnieniu od aspirantury naukowej dla pracujących zawodowo, wdrożonych niecałe dwa lata po uruchomieniu aspirantury naukowej zakazującej równoczesnej pracy zawodowej, studia doktoranckie do osób pracujących zaadresowano dopiero w 1968 r. ${ }^{44}$, zaś dwa i pół roku później (w 1971 r.) określono warunki ich kierowania na studia

${ }^{42}$ Podstawę tę tworzyły dwa artykuły ustawy z 1958 r. Pierwszy z nich (art. 48 ust. 3 i 4) sankcjonował prawo osoby kończącej studia w szkole wyższej do przyjęcia na studia doktoranckie oraz zobowiązał ministra szkolnictwa wyższego do określenia w drodze rozporządzenia kierunków studiów, na które mogą być przyjmowani doktoranci. Drugi przepis (art. 81 ust. 1) przewidywał możliwość przyznania osobie odbywającej studia doktoranckie stypendium naukowego.

${ }^{43}$ Rozporządzenie Ministrów Szkolnictwa Wyższego, Zdrowia i Opieki Społecznej, Oświaty, Spraw Zagranicznych oraz Przewodniczącego Głównego Komitetu Kultury Fizycznej i Turystyki z dnia 30 IV 1960 r. w sprawie zasad odbywania studiów doktoranckich w szkołach wyższych, praw i obowiązków doktorantów oraz wysokości stypendiów dla doktorantów.

${ }^{44}$ Zgodnie z \& 18 rozporządzenia Ministra Oświaty i Szkolnictwa Wyższego z dnia 15 II 1968 r. „[w] ramach liczby miejsc [...] mogą być przyjęte na studia doktoranckie osoby, które odbywałyby studia łącząc je z pracą zawodową". 
doktoranckie ${ }^{45}$. W $1976 \mathrm{r}$. niemal powtórzono rozwiązanie przyjęte w tym zakresie rozporządzeniem z $1968 \mathrm{r}^{46}{ }^{46}$, natomiast dziesięć lat później (w 1986 r.), w ślad za zmianą w 1985 r. ${ }^{47}$ ustawy z 1982 r. o szkolnictwie wyższym, wdrożono na podstawie ustawy z $1965 \mathrm{r}$. o stopniach naukowych i tytułach naukowych, w brzmieniu nadanym jej w 1973 r., nowe prawo tworzenia studiów doktoranckich, $\mathrm{w}$ tym dla osób pracujących, oraz warunki ich organizacji ${ }^{48}$. Biorąc zatem pod rozwagę ustawę z 1982 r. o szkolnictwie wyższym w brzmieniu pierwotnym, formułującą w przepisach przejściowych (art. 223) jedynie prawo ukończenia studiów doktoranckich na podstawie przepisów dotychczasowych, tj. rozporządzenia z 1976 r. (obowiązującego do 1986 r.), oraz uchwały nr 158 Rady Ministrów z 1971 r. (obowiązującej do października 1991 r.), trzeba przyjać, że począwszy od wejścia w życie ustawy z 1982 r. pozbawiono szkoły wyższe prawa rekrutacji na studia doktoranckie. Dopiero znowelizowana w 1985 r. ustawa z 1982 r. o szkolnictwie wyższym dała

${ }^{45}$ Uchwała nr 156 Rady Ministrów z dnia 30 VII 1971 r. w sprawie kierowania pracowników na studia doktoranckie dla pracujących oraz w sprawie ulg i świadczeń przysługujących tym pracownikom (M.P. Nr 45, poz. 287). Do kierowania pracowników na studia doktoranckie dla pracujących uprawniono trzy grupy podmiotów: (1) resortowe instytuty naukowo-badawcze, centralne laboratoria, biura konstrukcyjne i technologiczne, biura projektów, zakłady badań i doświadczeń, jak również przedsiębiorstwa, w których skład wchodziły komórki o charakterze i zakresie prac powyżej wymienionych placówek - w odniesieniu do pracowników naukowo-badawczych i inżynieryjno-technicznych; (2) ministerstwa, urzędy centralne, prezydia wojewódzkich rad narodowych (rad narodowych miast wyłączonych z województw) i zjednoczenia - w odniesieniu do posiadających duże doświadczenie praktyczne pracowników na stanowiskach kierowniczych lub równorzędnych, zajmujących się działalnością organizatorską, a wyjątkowo w odniesieniu do innych pracowników wykazujących się wybitnymi uzdolnieniami do pracy naukowo-badawczej; (3) inne jednostki gospodarki narodowej - w odniesieniu do grup powyżej podanych pracowników (tylko w szczególnie uzasadnionych przypadkach). Uchwałę tę uchylono dopiero w 1991 r. Zob. Załącznik do Uchwały nr 139 Rady Ministrów z dnia 11 X 1991 r. w sprawie uznania niektórych uchwał Rady Ministrów i Prezydium Rządu ogłoszonych w Dzienniku Urzędowym Rzeczypospolitej Polskiej "Monitor Polski" za nieobowiązujące (M.P. Nr 33, poz. 241).

${ }^{46}$ Różnica sprowadzała się jedynie do dookreślenia w 1976 r. zadań dla doktorantów (bez różnicowania, do kogo studia te są adresowane, i wyłączenia tej grupy z prawa do otrzymywania stypendiów).

${ }^{47}$ Ustawa z dnia 25 VII 1985 r. o zmianie ustawy o szkolnictwie wyższym (Dz.U. Nr 36, poz. 167). Zgodnie z jej art. 1 pkt 5 dodanemu art. 4 a nadano brzmienie: „[j]ednostki organizacyjne szkół uprawnione do nadawania stopnia naukowego doktora habilitowanego mogą, za zgodą Ministra Nauki i Szkolnictwa Wyższego, prowadzić studia doktoranckie".

${ }^{48}$ Zgodnie z $\$ 15$ ust. 1 rozporządzenia Ministra Nauki i Szkolnictwa Wyższego z dnia 10 VII 1986 r. w sprawie studiów doktoranckich i stypendiów naukowych. 
szkołom wyższym prawo tworzenia i prowadzenia studiów doktoranckich, a warunki dostępu do nich i przebiegu tych studiów określono rok później, w 1986 r. Z punktu widzenia zasad legislacyjnych rozwiązania te bez wątpienia były, w obecnej ocenie, kontrowersyjne, wtedy podyktowane - można założyć - pozaprawnym nakazem.

\subsection{Cele tworzenia i prowadzenia studiów doktoranckich}

Na mocy rozporządzenia z 1960 r. wprowadzaniu studiów doktoranckich miało przyświecać: stworzenie odpowiednich warunków do przyspieszenia kształcenia młodej kadry naukowej i uzyskania stopnia naukowego doktora $w$ zakresie dyscyplin naukowych szczególnie ważnych dla potrzeb gospodarki i kultury narodowej. Już w pierwszym roku lat sześćdziesiątych ubiegłego stulecia dostrzegano zatem potrzebę oparcia gospodarki, ale i kultury (później tylko gospodarki) na wiedzy (choć tego terminu wtedy nie używano), także na poziomie studiów doktoranckich (do 1968 r. prowadzonych wyłącznie dla osób niepracujących). Od tego ambitnego celu odstąpiono w 1968 r. rozporządzeniem ministra oświaty i szkolnictwa wyższego. Przyjęto w nim krótko: „[s]tudia doktoranckie mają na celu ułatwienie i przyspieszenie uzyskiwania stopni naukowych doktora w zakresie dziedzin nauki wymagających szczególnego wzrostu kadry naukowej". Cel studiów doktoranckich, tak zdefiniowany, miał być osiągnięty przez uczestników studiów doktoranckich (po raz pierwszy przyjęto to określenie) bez względu na to, czy były to studia kierowane do osób równocześnie pracujących czy tych, dla których ich łączenie z pracą zawodową nie było dopuszczalne. Od tego swego rodzaju dysonansu odstąpiono trzy lata później w preambule do uchwały nr 156 Rady Ministrów z dnia 30 lipca 1971 r. w sprawie kierowania pracowników na studia doktoranckie dla pracujących. Preambuła, odwołując się do postanowień uchwały IV Plenum Komitetu Centralnego Polskiej Zjednoczonej Partii Robotniczej, podkreślała potrzebę zintensyfikowania kształcenia kadr naukowych dla potrzeb gospodarki narodowej. Tym samym, przy zachowaniu celu studiów doktoranckich określonych rozporządzeniem z 1968 r., począwszy od $1971 \mathrm{r}$. kształcenie na potrzeby gospodarki narodowej lokowano przede wszystkich w obszarze studiów doktoranckich adresowanych do pracujących, bez oderwania ich od pracy zawodowej. W konsekwencji w 1976 r. powrócono do zamierzeń przewidzianych rozporządzeniem 
z 1960 r. Rozporządzenie ministra nauki, szkolnictwa wyższego i techniki z tegoż roku (1976) dostrzegało potrzebę prowadzenia studiów doktoranckich dla efektywnego i odpowiadającego potrzebom gospodarki narodowej kształcenia kadr naukowych w dziedzinach wymagających szczególnego wzrostu kadry naukowej. Przy czym tutaj tak zdefiniowany cel kształcenia dotyczył każdego uczestnika studium doktoranckiego (z oderwaniem i bez oderwania od pracy zawodowej). Od tego zamierzenia (celu) odstąiłiło rozporządzenie z 1986 r. $^{49}$ zapo- $^{-}$ wiadające zwiększenie efektywności kształcenia kadr naukowych w dyscyplinach i specjalnościach deficytowych lub priorytetowych.

Do czasu wdrożenia w $1991 \mathrm{r}$. nowych rozwiązań ${ }^{50}$ innego postrzegania celów uzasadniających prowadzenie studiów doktoranckich nie przewidziano.

Mimo ciągłych poszukiwań i w konsekwencji modyfikowania celów uzasadniających prowadzenie studiów doktoranckich niewątpliwą wartością było ich prawne określenie. Oczywiście, przyjęte cele nie pozostawały bez wpływu na możliwość tworzenia studiów doktoranckich przez jednostki organizacyjne szkół wyższych i innych instytucji, w tym placówek PAN. W konsekwencji nie były także bez znaczenia dla określenia warunków przyjęcia na studia doktoranckie.

\subsection{Warunki przyjęcia na studia doktoranckie}

Począwszy od 1960 r., warunki dostępu do studiów doktoranckich były dość zróżnicowane. Na mocy rozporządzenia z 1960 r. o przyjęcie na studia doktoranckie mogła się ubiegać osoba, która: (1) miała wszczęty przewód doktorski bądź spełniała warunki do jego wszczęcia ${ }^{51}$; (2) wyróżniała się zdolnościami i zamiłowaniem do pracy naukowej i pedagogicznej; (3) odbyła co najmniej dwuletnią praktykę naukową, pedagogiczną lub zawodowa, a w razie pracy nad rozprawą doktorską w zakresie nauk technicznych lub rolniczych - co najmniej dwuletni

${ }^{49}$ Rozporządzenie Ministra Nauki i Szkolnictwa Wyższego z dnia 19 VII 1986 r. w sprawie studiów doktoranckich i stypendiów naukowych.

${ }^{50}$ Rozporządzenie Ministra Edukacji Narodowej z dnia 10 VI 1991 r. w sprawie studiów doktoranckich i stypendiów naukowych (Dz.U. Nr 58, poz. 249).

${ }^{51}$ Zob. art. 78 ust. 2 ustawy z dnia 5 XI 1951 r. o szkołach wyższych, przewidujący warunki: posiadania tytułu magistra, magistra-inżyniera lub lekarza i zajmowania się pracą naukową co najmniej przez okres dwóch lat, przy możliwości jego skrócenia przez radę wydziału nie więcej niż o jeden rok. 
staż pracy produkcyjnej; (4) nie przekroczyła 35. roku życia; (5) złożyła zobowiązanie, że po uzyskaniu stopnia naukowego doktora w ramach studiów doktoranckich podejmie na wniosek rektora lub ministra pracę na stanowisku pomocniczego pracownika nauki w szkole wyższej co najmniej na okres trzech lat. $\mathrm{O}$ dopuszczeniu do studiów doktoranckich decydował minister, po złożeniu podania za pośrednictwem rektora, zaopiniowanego przez kierownika katedry i radę wydziału, a w przypadku kandydata mającego już wszczęty przewód doktorski również przez promotora.

Ustawa z 1965 r. i późniejsze rozporządzenia wydane na jej podstawie przyniosły inne rozwiązania. Przede wszystkim ustawa o stopniach naukowych i tytułach naukowych rozszerzyła krąg osób, którym mógł być nadany stopień doktora (poczynając od absolwentów studiów wyższych - studiów zawodowych - po osoby nielegitymujące się ukończeniem żadnych z tych studiów). Tego stanu rzeczy jej nowelizacje (w 1969, 1973 i 1985 r.) nie zmieniły. Do ustawowych postanowień dotyczących wykształcenia kandydata, jako jednego z warunków dostępu na studia, odsyłało natomiast każde z kolejno wydawanych rozporządzeń w sprawie zasad odbywania studiów doktoranckich $(1968,1976,1986)$. Oczywiście, wymagania dotyczące wykształcenia warunków tych nie wyczerpywały. Inne spośród nich, przyjmowane w kolejnych rozporządzeniach, zmieniały się.

Na mocy rozporządzenia z 1968 r. o przyjęcie na studia doktoranckie mogła się ubiegać osoba, która: (1a) ukończyła studia w szkole wyższej, uzyskując tytuł magistra, magistra-inżyniera, lekarza, oficera dyplomowanego lub inny równorzędny oraz wykazała uzdolnienia do pracy naukowo-badawczej albo (1b) ukończyła wyższą szkołę zawodową ${ }^{52}$, od 1969 r. studia zawodowe w szkole wyższej ${ }^{53}$ (odpowiednik dzisiejszych studiów licencjackich) lub studia równorzędne, jeżeli w toku pracy zawodowej osiągnęła rezultaty świadczące o jej szczególnych uzdolnieniach do pracy naukowo-badawczej (co podkreślało precyzyjniej sformułowany warunek przyjęty rozporządzeniem z 1960 r.),

${ }^{52}$ Moca art. 3 ust. 1 Ustawy z dnia 20 XII 1968 r. o zmianie ustawy o szkolnictwie wyższym (Dz.U. Nr 46, poz. 334) wyższe szkoły zawodowe stały się z dniem jej wejścia w życie (tj. od dnia 27 XII 1968 r.) szkołami wyższymi.

${ }^{53}$ Zob. art. 4 ust. 1 pkt 1 ustawy z dnia 31 III 1965 r. w brzmieniu nadanym tekstem jednolitym tej ustawy w 1969 r. (Obwieszczenie Przewodniczącego Komitetu Nauki i Techniki z dnia 27 I 1969 r. w sprawie ogłoszenia jednolitego tekstu ustawy z dnia 31 III 1965 r. o stopniach naukowych i tytułach naukowych - Dz.U. Nr 4, poz. 32). 
albo (1c) mimo iż studiów wyższych nie ukończyła, w szczególnych przypadkach wykazała się zasobem wiedzy i dorobkiem naukowym świadczącym o przygotowaniu i uzdolnieniu do pracy naukowo-badawczej, co z mocy ustawy z 1965 r. wymagało w zakresie szkół wyższych uzyskania zgody ministra szkolnictwa wyższego, a w zakresie pozostałym zgody sekretarza naukowego PAN ${ }^{54}$. Warunek ten rozporządzenie z 1968 r. uzupełniało przez obowiązek złożenia z pomyślnym wynikiem kolokwium, stwierdzającego zainteresowanie kandydata praca naukową i jego dostateczne przygotowanie do studiów doktoranckich ${ }^{55}$; (2) nie przekroczyła 35 lat, przy czym od tego warunku, w uzasadnionych wypadkach, właściwy minister (sekretarz PAN) mógł odstąpić. Regulamin organizacyjny studiów doktoranckich mógł wprowadzić, jako warunek dopuszczenia do studiów doktoranckich, określony staż naukowy lub zawodowy kandydata (co podkreślało pewne odstępstwo od centralnego kierowania w tym zakresie). O dopuszczeniu do odbywania studiów doktoranckich już nie decydował minister, lecz rektor - w szkole wyższej, kierownik - w placówce PAN, a w instytucie naukowo-badawczym oraz $\mathrm{w}$ samodzielnej placówce typu naukowo-dydaktycznego - dyrektor, po zasięgnięciu opinii odpowiedniej rady (wydziału, naukowej).

Wraz z wprowadzeniem w 1971 r. studiów doktoranckich dla pracujących warunki dostępu do nich radykalnie zminimalizowano. Od kierowanych na te studia wymagano jedynie spełnienia dwóch warunków. Pierwszy z nich określała ustawa z 1965 r. o stopniach naukowych i tytułach naukowych, w brzmieniu nadanym w 1969 r. (wykształcenie wyższe, zawodowe, bez takiego wykształcenia $)^{56}$. Drugi warunek wiązano z wykazaniem właściwej postawy społeczno-politycznej kandydata.

${ }^{54}$ Zob. $\S 6$ ust. 1 rozporządzenia z dnia 15 II 1968 r. w zw. z art. 4 ust. 1 pkt 1, ust. 2 i ust. 3 ustawy z dnia 31 III 1965 r. o stopniach naukowych i tytule naukowym - w brzmieniu pierwotnym.

${ }^{55}$ Zakres kolokwium określała rada (wydziału, naukowa), kandydat zdawał je przed komisją powołaną przez radę ( $\$ 6$ ust. 3 rozporządzenia z dnia 15 II 1968 r.).

${ }^{56} \mathrm{Na}$ studia doktoranckie dla pracujących mogły być skierowane osoby: z tytułem magistra-inżyniera, lekarza, oficera dyplomowanego lub innym tytułem równorzędnym wykazujące uzdolnienia do pracy naukowo-badawczej; absolwenci studiów zawodowych w szkole wyższej, jeśli w pracy zawodowej osiągnęli rezultaty świadczące o szczególnych uzdolnieniach do pracy naukowo-badawczej, a także niekończące żadnej szkoły wyższej, lecz wykazujące się zasobem wiedzy i dorobkiem naukowym świadczącym o przygotowaniu i uzdolnieniu do pracy naukowo-badawczej - w tym przypadku w odniesieniu do szkół wyższych - za zgodą ministra, w pozostałym zakresie - sekretarza naukowego PAN. 
Decyzja w tej sprawie miała być uzgodniona z radą zakładową ${ }^{57}$. Tym samym, począwszy od 1971 r., do tej grupy nie miały zastosowania inne warunki, mocą rozporządzenia z $1968 \mathrm{r}$. wymagane od pozostałych kandydatów, w dostępie na studia doktoranckie ${ }^{58}$. Tego stanu rzeczy nie zmieniły rozporządzenia z 1976 i $1986 \mathrm{r}^{59}$

Począwszy od 1976 r., droga dostępu do studiów doktoranckich uległa pewnej zmianie. Na studia doktoranckie mogła być przyjęta osoba, która: (1) odpowiadała warunkom określonym w ustawie z 1965 r. o stopniach naukowych i tytułach naukowych w brzmieniu nadanym ustawą z 1973 r. $^{60}$; (2) złożyła przed komisją egzaminacyjną powołaną przez radę wydziału (radę naukową) egzamin z wynikiem pozytywnym $^{61}$ - $\mathrm{i}$ to było rozwiązanie nowe (znacznie odbiegające od istoty kolokwium z 1968 r.); (3) nie przekroczyła 35. roku życia; (4) odbyła co

${ }_{57}$ Zob. § 2 ust. 2 uchwały nr 156 Rady Ministrów z dnia 30 VII 1971 r. oraz $§ 3$ tej uchwały, zgodnie z którym "[s]kierowanie na studia powinno być uzależnione od złożenia zobowiązania, że pracownik po ukończeniu studiów będzie pracował w zakładzie pracy przez okres co najmniej 3 lat na stanowisku odpowiadającym jego kwalifikacjom".

${ }^{58}$ Zob. § 18 zd. 2 rozporządzenia Ministra Oświaty i Szkolnictwa Wyższego z dnia 15 II 1968 r. w sprawie zasad odbywania studiów doktoranckich, wyraźnie uchylające warunki rekrutacji na studia przyjęte tym rozporządzeniem wobec osób kierowanych na studia doktoranckie dla pracujących.

${ }^{59}$ Zob. § 18 zd. 2 rozporządzenia Ministra Nauki, Szkolnictwa Wyższego i Techniki z dnia 17 XII 1976 r. w sprawie studiów doktoranckich oraz $\S 15$ ust. 2 rozporządzenia Ministra Nauki i Szkolnictwa Wyższego z dnia 10 VII 1986 r.

${ }^{60}$ Zob. $\S 8$ ust. 1 rozporządzenia z dnia 17 XII 1976 r., w zw. z art. 4 ust. 1 pkt 1 oraz ust. 2 i 3 ustawy z dnia 31 III 1965 r. o stopniach naukowych i tytułach naukowych w brzmieniu nadanym Obwieszczeniem Ministra Nauki, Szkolnictwa Wyższego i Techniki z dnia 10 VII 1973 r. w sprawie obwieszczenia jednolitego tekstu ustawy z dnia 31 III 1965 r. o stopniach naukowych i tytułach naukowych (Dz.U. Nr 32, poz. 192). Zgodnie z nimi o przyjęcie na studia doktoranckie mogła się ubiegać osoba, która: ukończyła szkołę wyższą, uzyskując tytuł magistra, magistra-inżyniera, lekarza, oficera dyplomowanego lub inny równorzędny, oraz wykazała uzdolnienia do pracy naukowo-badawczej albo ukończyła wyższą szkołę zawodową lub studia równorzędne, jeżeli w toku pracy zawodowej osiągnęła rezultaty świadczące o jej szczególnych uzdolnieniach do pracy naukowo-badawczej, albo w szczególnych przypadkach, choć studiów wyższych nie ukończyła, wykazała się zasobem wiedzy i dorobkiem naukowym świadczącym o przygotowaniu i uzdolnieniu do pracy naukowo-badawczej.

${ }^{61}$ Egzaminem objęto dziedzinę nauki, w której kandydat zamierzał otworzyć przewód doktorski, a także jego znajomości języka obcego przydatnego w danej specjalności. Szczegółowe określenie egzaminów pozostawiono radzie wydziału (radzie naukowej). Po zasięgnięciu opinii komisji egzaminacyjnej rada wydziału (rada naukowa) mogła zwolnić w całości lub w części z egzaminu kandydata, jednakże tylko tego, który o przyjęcie na studia doktoranckie ubiegał się bezpośrednio po studiach wyższych ukończonych $\mathrm{z}$ wyróżnieniem lub z wynikiem bardzo dobrym. 
najmniej dwuletni staż pracy zawodowej odpowiadającej kierunkowi studiów doktoranckich (rozwiązanie nieco zmodyfikowane); (5) wykazała właściwą postawę ideową i obywatelską (co było rozwiązaniem nowym). Do odbywania tych studiów, w uzasadnionych wypadkach, rada wydziału (rada naukowa) jednostki prowadzącej studia doktoranckie mogła jednak dopuścić osobę: (1) niespełniającą warunku wymaganego wieku, jak i tę, która (2) warunku co najmniej dwuletniego stażu pracy zawodowej nie spełniała, ale ukończyła studia wyższe z wyróżnieniem lub wynikiem bardzo dobrym, a praktyka zawodowa nie była konieczna w zakresie tematyki jej pracy doktorskiej (co było wówczas także rozwiązaniem nowym).

O przyjęciu na studia doktoranckie, $w$ ramach liczby miejsc ustalonej przez organ powołany do tworzenia studiów, decydował kierownik jednostki prowadzącej studia doktoranckie po zasięgnięciu opinii komisji do spraw studiów doktoranckich lub opinii rady wydziału (rady naukowej), co bez wątpienia łagodziło znacznie system centralistycznego zarządzania szkołami wyższymi, w tym prowadzenia studiów doktoranckich.

Rok 1986 w zakresie warunków wymaganych od kandydatów na studia doktoranckie przyniósł pewne zmiany. Na studia te mogła być przyjęta osoba, która: (1) odpowiadała warunkom określonym w ustawie z 1965 r. o stopniach naukowych i tytułach naukowych w brzmieniu nadanym ustawą z 1985 r. $^{62}$; (2) odbyła co najmniej dwuletni staż pracy zawodowej odpowiadającej kierunkowi studiów; w dyscyplinach teoretycznych kandydatami mogły być osoby mające roczny staż naukowy lub zawodowy; (3) absolwenci szkół wyższych posiadający dyplom z wyróżnieniem mogli ubiegać się o przyjęcie na studia doktoranckie bezpośrednio po ukończeniu studiów wyższych; opinię co do ich nienagannej postawy obywatelskiej mieli wydawać kierownicy jednostek kierujących kandydatów (po raz pierwszy przyjęte rozwiązanie); (4) posiadała skierowanie lub zgodę zakładu pracy; (5) wykazywała nienaganną postawę obywatelską, potwierdzoną opinią wydaną przez

${ }^{62} \mathrm{Na}$ studia te mogła być przyjęta osoba, która: (1) ukończyła studia w szkole wyższej, uzyskując tytuł magistra, magistra inżyniera, lekarza, oficera dyplomowanego lub inny równorzędny oraz wykazała uzdolnienia do pracy naukowo-badawczej, albo (2) ukończyła studia zawodowe w szkole wyższej lub studia równorzędne, jeżeli w toku pracy zawodowej osiągnęła rezultaty świadczące o szczególnych uzdolnieniach do pracy naukowo-badawczej lub w wyjątkowych przypadkach, (3) nie kończąc studiów w szkole wyższej, wykazała się zasobem wiedzy i dorobkiem naukowym świadczącym o przygotowaniu i uzdolnieniu do pracy naukowo-badawczej. 
kierowników jednostek kierujących kandydatów w uzgodnieniu z organizacją partyjną działająca $\mathbf{w}$ jednostce (co bez wątpienia było rozwiązaniem nowym i zaostrzającym warunki dostępu); (6) nie przekroczyła 30 lat (obniżono tu wiek kandydata); (7) była urzędnikiem państwowym, z którym stosunek pracy został rozwiązany do dnia 31 grudnia 1988 r. ${ }^{63}$; (8) złożyła egzamin z wynikiem pozytywnym ${ }^{64}$.

Zmiany zaostrzające rozwiązania dotyczyły także kwestii formalnych. Po pierwsze - kandydatów na studia doktorskie mieli kierownikowi studium doktoranckiego zgłaszać rektorzy szkół wyższych, dyrektorzy placówek naukowych PAN i jednostek badawczo-rozwojowych lub dyrektorzy jednostek gospodarki uspołecznionej oraz innych instytucji, w których kandydaci byli zatrudnieni. Po drugie - decyzję o przyjęciu na studia doktoranckie podejmował minister nadzorujący szkołę wyższa, instytut naukowo-badawczy lub samodzielną placówkę typu naukowo-dydaktycznego albo sekretarz naukowy PAN w odniesieniu do placówki naukowej PAN (co było powrotem do rozwiązań przyjętych rozporządzeniem z $1960 \mathrm{r}$. i zaostrzało rozwiązania z roku 1968 i 1976), na wniosek przedstawiony przez kierownika jednostki organizacyjnej prowadzącej studium doktoranckie, przygotowany przez kierownika studium. Wniosek miał zawierać również proponowane kandydatury opiekunów naukowych.

Nowe, zdecydowanie pozytywne, było natomiast rozwiązanie wymagające podawania do publicznej wiadomości - w formie ogłoszeń prasowych i informacji wywieszanych w siedzibie jednostki prowadzącej studia doktoranckie - warunków przyjęcia na studia doktoranckie.

Do chwili wejścia w życie nowych rozwiązań wprowadzonych w 1991 r. ${ }^{65}$ warunki przyjęcia na studia doktoranckie nie zostały zmienione.

${ }^{63}$ Punkt siódmy został dodany na podstawie Rozporządzenia Ministra Edukacji Narodowej z dnia 18 IV 1988 r. zmieniającego rozporządzenie w sprawie studiów doktoranckich i stypendiów naukowych (Dz.U. Nr 14, poz. 105).

${ }^{64}$ Zgodnie z \& 6 ust. 2 i 3 rozporządzenia Ministra Nauki i Szkolnictwa Wyższego z dnia 10 VII 1986 r. kandydat składał egzamin przed komisją egzaminacyjną powołaną przez kierownika jednostki organizacyjnej (w szkole wyższej - dziekana) na wniosek kierownika studium doktoranckiego. Egzaminem objęto dyscyplinę, w której kandydat zamierzał otworzyć przewód doktorski, oraz język obcy. Szczegółowy zakres egzaminów ustalała rada wydziału (rada naukowa) lub komisja do spraw studiów doktoranckich.

${ }^{65}$ Zob. Rozporządzenie Ministra Edukacji Narodowej z dnia 10 VI 1991 r. w sprawie studiów doktoranckich i stypendiów naukowych. 


\subsection{Organizacja i przebieg studiów doktoranckich}

Zasady organizacji i przebieg studiów doktoranckich nie były przedmiotem materii ustawowej. Podstawowe znaczenie dla wyznaczenia ram organizacyjnych i przebiegu tych studiów wyznaczały kolejno obowiązujące przepisy wykonawcze. Najważniejsze uwarunkowania nimi przyjęte, począwszy od 1960 r., sprowadzały się (w nierównym stopniu) do czterech adresatów: właściwych ministrów, organów szkół wyższych, kierowników naukowych oraz osób przyjętych na studia doktoranckie, zaś w odniesieniu do studiów doktoranckich dla pracujących także do zakładów pracy kierujących swych pracowników na studia.

W odniesieniu do pierwszego adresata, mocą rozporządzenia z 1960 r. to właściwi ministrowie po zasięgnięciu opinii Rady Głównej Szkolnictwa Wyższego ustalali ramowy program i regulamin studiów doktoranckich oraz sprawowali ogólny nadzór nad studiami doktoranckimi. Na podstawie rozporządzenia z 1968 r. ustalenie ramowego programu studiów doktoranckich pozostawiono w gestii: (1) ministra oświaty i szkolnictwa wyższego w odniesieniu do szkół wyższych i podległych mu samodzielnych placówek naukowo-dydaktycznych w porozumieniu z sekretarzem naukowym PAN, (2) w szkołach wyższych i w samodzielnych placówkach typu naukowo-dydaktycznego podległych innemu ministrowi oraz w instytutach naukowo-badawczych - właściwego ministra w porozumieniu $\mathrm{z}$ ministrem oświaty i szkolnictwa wyższego oraz z sekretarzem naukowym PAN, (3) w placówkach naukowych PAN - sekretarza naukowego PAN działającego w porozumieniu z ministrem oświaty i szkolnictwa wyższego. Zarazem rozporządzeniem tym określono, nieenumeratywnie, zajęcia objęte programem studiów doktoranckich jako obowiązkowe na wszystkich kierunkach studiów doktoranckich (seminaria z dziedziny nauki lub dyscypliny naukowej, w których zakresie jednostka prowadząca studia doktoranckie miała prawo nadawania stopnia naukowego doktora; konsultacje indywidualne udzielane uczestnikowi studiów doktoranckich przez wyznaczonego kierownika naukowego ${ }^{66}$ ), jak i te, o których charakterze miał przesądzać program szczegółowy. Chodziło tu o ćwiczenia, konwersatoria, wykłady itp. zajęcia z dyscypliny naukowej oraz

${ }^{66}$ Zajęcia te mogły być organizowane tylko w jednostce prowadzącej studia doktoranckie ( $\$ 4$ rozporządzenia z 1968 r.). 
z dyscyplin dodatkowych, stanowiących przedmiot egzaminu doktorskiego ${ }^{67}$ - ustalany przez radę (wydziału, naukową).

Z kolei w myśl rozporządzenia z $1976 \mathrm{r}$. ustalenie ramowego programu studiów doktoranckich pozostawiono w gestii, z wyjątkiem wspólnych studiów doktoranckich ${ }^{68}$ i studiów w zakresie nauk wojskowych ${ }^{69}$, właściwych ministrów (kierowników urzędów centralnych) lub sekretarza naukowego PAN działającego $\mathrm{w}$ porozumieniu $\mathrm{z}$ ministrem nauki, szkolnictwa wyższego i techniki. Rozporządzenie to wyznaczało ponadto zasady i warunki ustalania programu studiów doktoranckich ${ }^{70}$. Zgodnie zaś z rozporządzeniem z 1986 r. minister nauki i szkolnictwa wyższego, w porozumieniu z sekretarzem naukowym PAN i ministrami nadzorującymi pozostałe szkoły wyższe, instytuty naukowo-badawcze lub samodzielne placówki typu naukowo-dydaktycznego, określał zasady opracowywania planów i programów studiów doktoranckich ${ }^{71}$,

${ }^{67}$ Jeżeli ich prowadzenie przez jednostkę organizacyjną prowadzącą studia doktoranckie nie było możliwe lub było utrudnione, na niej spoczywał obowiązek zapewnienia uczestnikom studiów doktoranckich korzystania z zajęć, na podstawie porozumienia prowadzonych przez inną instytucję, bądź ich zorganizowania wspólnie w dwu lub więcej jednostkach uprawnionych do nadawania stopnia naukowego doktora ( $\$ 4 \mathrm{w} \mathrm{zW}$. z § 1 ust. 1 rozporządzenia z 1968 r.).

${ }^{68}$ Można je było tworzyć w dziedzinach i dyscyplinach nauk takich samych lub ściśle ze sobą powiązanych ( $\$ 2$ ust. 2 rozporządzenia z dnia 17 XII 1976 r. w sprawie studiów doktoranckich).

${ }^{69}$ Zob. $\S 3$ ust. 1 i 2 rozporządzenia z dnia 17 XII 1976 r. w sprawie studiów doktoranckich.

${ }^{70}$ W myśl § 5 ust. 1 rozporządzenia Ministra Nauki, Szkolnictwa Wyższego i Techniki z dnia 17 XII 1976 r. program studiów miał być tak ustalony, aby: (1) otwarcie przewodu doktorskiego nastąpiło nie później niż w ciągu roku od daty rozpoczęcia studiów; (2) wykonywanie pracy doktorskiej było zgodne $z$ harmonogramem ustalonym przez kierownika naukowego i zatwierdzonym przez radę (wydziału, naukową); (3) złożenie egzaminu doktorskiego z dyscypliny dodatkowej odbyło się nie później niż w ciągu trzeciego semestru studiów, a z dyscypliny podstawowej odpowiadającej tematowi rozprawy doktorskiej - przed zakończeniem piątego semestru studiów, natomiast złożenie rozprawy doktorskiej nastąpiło przed zakończeniem studiów; (4) przyjęcie rozprawy doktorskiej i jej obrona były możliwe bezpośrednio po ukończeniu studiów doktoranckich. Obciążenie zajęciami obowiązkowymi nie mogło przekraczać czterystu godzin w okresie trwania studiów, a zajęciami dydaktycznymi - trzech godzin tygodniowo.

${ }^{71}$ Zgodnie z \& 5 ust. 1 rozporządzenia z dnia 10 VII 1986 r. plany i programy studiów doktoranckich miały uwzględniać: „1) liczbę godzin zajęć obowiązkowych, w tym liczbę godzin zajęć z przedmiotów społeczno-politycznych, metodyki i techniki prowadzenia pracy naukowo-badawczej i dydaktycznej oraz z języków obcych. 2) liczbę obowiązkowych egzaminów i zaliczeń. 3) obowiązkowy wymiar zajęć dydaktycznych, w których prowadzeniu powinien brać udział uczestnik studiów doktoranckich". Pomijając grupę przedmiotów politycznych, wprowadzone w 1986 r. rozwiązania można w dużej mierze 
zarazem wymagając takiego opracowania planu studiów, aby wniosek o wszczęcie przewodu doktorskiego został przedstawiony radzie (wydziału, naukowej) nie później niż w ciągu roku od daty rozpoczęcia studiów.

W odniesieniu do drugiego adresata, mocą rozporządzenia z $1960 \mathrm{r}$. do rady wydziału należała ogólna kontrola nad przebiegiem prowadzonych studiów doktoranckich, a do dziekana sporządzanie sprawozdań z okresowej ich oceny wraz z wynikami pracy poszczególnych doktorantów. Senat, opierając się na przedłożonych sprawozdaniach, raz do roku dokonywał ogólnej oceny studiów doktoranckich na poszczególnych wydziałach, a rektor w końcu roku szkolnego przedstawiał właściwemu ministrowi sprawozdanie z przebiegu i wyników studiów doktoranckich za dany rok.

Rozporządzenie z 1968 r. od tego stopnia szczegółowości rozwiązań nie odbiegało, co więcej, wprowadzało rozwiązania nowe. Stanowiło, że nadzór (a więc nie tylko kontrolę) nad studiami doktoranckimi sprawuje rada wydziału (rada naukowa). Dla wykonywania określonych czynności nadzoru rada wydziału (rada naukowa) mogła powołać komisję złożoną z 3-5 członków. Rada (wydziału, naukowa) ustalała szczegółowy program studiów doktoranckich (określając nim zajęcia uczestników studiów, ich rozdział na poszczególne zajęcia ${ }^{72}$ oraz wymiar godzin ${ }^{73}$, mogła także przewidzieć nim prowadzenie przez uczestników zajęć dydaktycznych, w wymiarze nieprzekraczającym dwunastu godzin tygodniowo) oraz regulamin organizacyjny. Studiami doktoranckimi kierował kierownik, powoływany w szkole wyższej przez rektora (co także było nowym rozwiązaniem), w placówce naukowej

odnieść do unormowań przyjętych w 2011 r. i dookreślonych w 2014 r. Rozporządzeniem Ministra Nauki i Szkolnictwa Wyższego z dnia 24 X 2014 r. - Dz.U. poz. 1480), z jedną tylko różnicą - liczbę godzin zastąpiono punktami ECTS wymaganymi do zaliczania modułów objętych programem i planem studiów doktoranckich, z obowiązkowym uwzględnieniem nimi nauk humanistycznych.

${ }^{72}$ Co więcej, plan (program) studiów każdego uczestnika studiów doktoranckich miał być tak ustalony, aby złożenie egzaminów doktorskich mogło nastąpić przed zakończeniem studiów doktoranckich, a przyjęcie rozprawy doktorskiej i jej obrona były możliwe bezpośrednio po ukończeniu studiów doktoranckich (§9 ust. 2 rozporządzenia z 1968 r.).

${ }^{73}$ Jednostka prowadząca studia doktoranckie miała organizować zajęcia, opierając się na własnej kadrze naukowej i własnych urządzeniach. W razie potrzeby mogła jednak korzystać z pomocy innych pracowników naukowo-dydaktycznych i naukowo-badawczych (na podstawie umowy zlecenia lub umowy o dzieło), a także z urządzeń należących do innej instytucji na podstawie odpowiedniego porozumienia ( $\$ 4$ ust. 2-4 rozporządzenia z 1968 r.). 
PAN przez sekretarza wydziału, a w instytucie naukowo-badawczym i samodzielnej placówce typu naukowo-dydaktycznego przez właściwego ministra na wniosek rady wydziału (rady naukowej). Kierownik studiów doktoranckich składał radzie okresowe sprawozdania (co najmniej raz na pół roku).

Rozporządzenie z 1976 r. pozostawiło sprawowanie nadzoru nad studiami doktoranckimi radzie wydziału (radzie naukowej) i w jego ramach dokonywanie oceny postępów w pracy naukowej poszczególnych uczestników studiów doktoranckich, a kierowanie tymi studiami ich kierownikowi. Kierownika studium doktoranckiego powoływał rektor lub dyrektor jednostki prowadzącej studia doktoranckie. $\mathrm{Na}$ kierowniku studium spoczywał obowiązek składania radzie raz w semestrze okresowych sprawozdań. Dziekan (inny kierownik) jednostki prowadzącej studia doktoranckie powoływał na wniosek rady komisję do spraw studiów doktoranckich. Komisja ta miała dokonywać oceny stanu zaawansowania prac doktorskich, ich poziomu oraz zgodności realizacji z harmonogramem. Senat szkoły wyższej na podstawie sprawozdań rady wydziału (rady naukowej) co najmniej raz w roku dokonywał oceny efektywności studiów doktoranckich prowadzonych przez szkołę wyższą oraz wyników pracy kierowników naukowych. Wyniki przeprowadzonej oceny senat przedstawiał właściwemu ministrowi. Kierownik jednostki organizacyjnej prowadzącej studia doktoranckie wyznaczał dla każdego uczestnika studium, w porozumieniu z kierownikiem studiów i komisją do spraw studiów doktoranckich, kierownika naukowego spośród osób mających tytuł naukowy profesora, stopień naukowy doktora habilitowanego oraz osób mających stopień naukowy doktora, zajmujących stanowiska docentów.

Począwszy od 1986 r., sprawowanie nadzoru nad działalnością studium doktoranckiego pozostawiono $w$ gestii dziekana lub dyrektora placówki naukowej PAN albo dyrektora instytutu naukowo-badawczego lub samodzielnej placówki typu naukowo-dydaktycznego. Dziekan (dyrektor) mógł także powołać komisję do spraw studium doktoranckiego, złożoną z profesorów i docentów ze stopniem naukowym, a w przypadku studium środowiskowego ${ }^{74}$ - również spośród zatrudnionych poza

${ }^{74}$ Zgodnie z $§ 1$ ust. 3 rozporządzenia Ministra Nauki i Szkolnictwa Wyższego z dnia 10 VII 1986 r. doktoranckie studia jako studia środowiskowe mogły być prowadzone przez jednostki organizacyjne szkół wyższych, placówki naukowe PAN, instytuty naukowo-badawcze lub samodzielne placówki typu naukowo-dydaktycznego - posiadające uprawnienia do nadawania stopnia naukowego doktora habilitowanego, przy udziale kadr 
jednostką prowadzącą studium doktoranckie. Komisji tej przewodniczył kierownik studium. Kierownik studium miał nadto obowiązek dokonywania w każdym semestrze oceny postępów w pracy naukowej uczestników studiów doktoranckich, a po zakończeniu każdego roku akademickiego przedstawienia jej rektorowi, w uzgodnieniu z kierownikiem danej jednostki organizacyjnej (dziekanem, dyrektorem placówki PAN, instytutu). Wyniki dokonanej w ten sposób oceny studiów doktoranckich dziekan, dyrektor placówki PAN albo dyrektor instytutu przedstawiał, odpowiednio, właściwemu ministrowi lub sekretarzowi naukowemu PAN. Rada wydziału (rada naukowa) lub komisja do spraw studium doktoranckiego, na wniosek kierownika studium, wyznaczała przy przyjęciu kandydatów na studia doktoranckie opiekunów naukowych spośród profesorów lub docentów ze stopniem naukowym.

W odniesieniu do trzeciego adresata, rozporządzenie z $1960 \mathrm{r}$. obowiązków bezpośredniego opiekuna naukowego doktoranta nie określało. Dość zdawkowo je definiowało rozporządzenie z 1968 r.: "[k]ierownik naukowy udziela pomocy uczestnikowi studiów w jego osobistej pracy naukowej, a w szczególności w zakresie przygotowania rozprawy doktorskiej, odbywa z nim konsultacje i sprawdza postępy $\mathrm{w}$ jego rozwoju naukowym". W porozumieniu z kierownikiem naukowym powinien być ustalony temat rozprawy doktorskiej. Mocą uchwały nr 156 Rady Ministrów z 1971 r. zakład pracy mógł zgłaszać wnioski w sprawie doboru tematyki pracy doktorskiej pracownika, którego skierował na studia doktoranckie dla pracujących, i był upoważniony do uzyskiwania od kierownika studiów doktoranckich bądź opiekuna naukowego informacji o przebiegu i postępach w studiach swego pracownika.

Rozporządzenie z 1976 r. dodawało udział kierownika naukowego „W otwarciu przewodu doktorskiego, opracowaniu harmonogramu pracy doktorskiej, odbywanie z nim konsultacji, oceny w postępach rozwoju naukowego oraz zaawansowaniu pracy doktorskiej i pomaganie w jej przygotowaniu". Tenże kierownik uczestniczył w ocenie poszczególnych części prac swoich podopiecznych, dokonywanej przez komisję do spraw studiów doktoranckich. W razie nienależytego wykonywania obowiązków w tym zakresie kierownik jednostki prowadzącej studia doktoranckie (a nie rada wydziału, naukowa) mógł odwołać kierownika

naukowych innych jednostek organizacyjnych oraz wykorzystaniu bazy aparaturowej i socjalnej tych jednostek. Repartycję zadań jednostek organizacyjnych prowadzących studia środowiskowe miały określać umowy zawarte pomiędzy nimi. 
naukowego. W dzisiejszej ocenie rozwiązanie to trudno ocenić pozytywnie, chociażby dlatego, że kierownik jednostki organizacyjnej mógł być zarazem kierownikiem naukowym uczestnika (uczestników) studiów doktoranckich, co stawiało go w pozycji wyłączonej spod kontroli. Z kolei rozporządzenie z 1986 r. od określenia praw i obowiązków opiekuna naukowego odstąpiło.

W odniesieniu do czwartego adresata, w myśl rozporządzenia z 1960 r. osoba przyjęta na studia doktoranckie była $z$ tytułu podległości dziekanowi zobowiązana do: systematycznej pracy naukowej, w szczególności związanej z opracowaniem rozprawy doktorskiej i przygotowaniem się do egzaminów doktorskich oraz nabyciem umiejętności prowadzenia prac naukowo-badawczych, uczestniczenia w wykładach, seminariach i innych zajęciach ustalonych w programie studiów doktoranckich oraz brania udziału w zebraniach naukowych katedry i składania w wyznaczonych terminach sprawozdań z przebiegu własnej pracy naukowej. Doktorant nie mógł wykonywać żadnych stałych ani okresowych zajęć zarobkowych. Zakaz ten obejmował także pomocniczego pracownika szkoły wyższej przyjętego na studia doktoranckie, któremu z tego tytułu w okresie studiów doktoranckich udzielano urlopu bezpłatnego.

Od tych rozwiązań nie odbiegały postanowienia rozporządzenia z 1968 r. Uczestnik studiów doktoranckich w okresie ich odbywania był obowiązany do: systematycznej pracy naukowej związanej z opracowaniem rozprawy doktorskiej i przygotowaniem się do egzaminów doktorskich; uczestniczenia w zajęciach obowiązkowych ustalanych w programie studiów oraz w zajęciach przez siebie wybranych; brania udziału w zebraniach naukowych wskazanych przez kierowników naukowych; składania w wyznaczonych terminach sprawozdań z przebiegu swojej pracy naukowej. Obowiązki te w równej mierze dotyczyły także osób przyjętych na studia doktoranckie łączących je z pracą zawodową ( 18 rozporządzenia z $1968 \mathrm{r}$.), w tym pracowników skierowanych na studia doktoranckie dla pracujących zawodowo (1971 r.).

Innej filozofii podporządkowano określenie obowiązków uczestników studiów doktoranckich w rozporządzeniu z 1976 r. Tu ich udział w realizacji programu studiów sprowadzono do: (1) udziału w pracach naukowo-badawczych jednostki prowadzącej studia w zakresie problematyki związanej z pracą doktorską; w zajęciach specjalnych z dyscypliny podstawowej (seminaria, konwersatoria, praktyki, wykłady monograficzne) związanych z przewodem doktorskim, określonych w programie studiów; zajęciach z dyscypliny dodatkowej (ekonomii politycznej lub 
filozofii); (2) prowadzenia zajęć dydaktycznych w wymiarze określonym przez kierownika naukowego lub promotora; (3) przedstawiania na seminariach doktoranckich co najmniej raz w semestrze części pracy doktorskiej przewidzianej w harmonogramie.

Podobne rozwiązania przyjęto w 1986 r. Rozporządzeniem z tego roku uczestników studiów doktoranckich zobowiązano do: (1) udziału w pracach naukowo-badawczych i przygotowania do egzaminów doktorskich; (2) uczestniczenia w ustalonych programem studiów zajęciach i składania w wyznaczonych terminach sprawozdań z przebiegu pracy naukowej; (3) uczestniczenia w prowadzeniu zajęć dydaktycznych stosownie do wymiaru określonego programem studiów; (4) przedstawiania na seminariach doktoranckich przynajmniej raz $\mathrm{w}$ semestrze kolejnych fragmentów pracy doktorskiej; (5) złożenia egzaminów doktorskich i przedłożenia pracy doktorskiej w przewidzianym programem studiów terminie; (6) przedstawienia rozprawy doktorskiej.

Wypełnienie tych obowiązków wyznaczono limitem czasowym trwania studiów doktoranckich. I choć czasu ich trwania nie zakreślono terminem zawitym, był on bardzo ambitnie wyznaczony. Z mocy rozporządzenia z 1960 r. studia doktoranckie w zależności od charakteru i dyscypliny naukowej miały trwać do czterech lat ( 11 ust. 3). Mogły zatem trwać odpowiednio krócej, lecz nie dłużej. Krótszy termin ich odbywania przewidywały rozporządzenia z 1968 i 1976 r. Zgodnie z nimi czas trwania studiów doktoranckich wyznaczono terminem do lat trzech ( $\S 3$ ust. 5 rozporządzenia z 1968 r. oraz $\S 5$ ust. 3 rozporządzenia z 1976 r.). Mocą rozporządzenia zmieniającego z $1980 \mathrm{r}^{75}$ okres trwania studiów w przypadkach losowych mógł być przedłużony do lat czterech, za zgodą ministra nauki, szkolnictwa wyższego i techniki działającego w porozumieniu z sekretarzem naukowym PAN w szkołach wyższych i samodzielnych placówkach typu naukowo-dydaktycznego podległych temu ministrowi. W roku 1986 r. ponownie przywrócono czas trwania studiów do lat czterech, ale już z możliwością ich przedłużenia nie więcej niż o jeden rok, za zgodą właściwego ministra lub sekretarza naukowego PAN. Tylko rozstrzygnięcie pozytywne w tym zakresie (wyrażenie zgody) wymagało formy decyzji.

Doktorant naruszający przepisy rozporządzenia z 1960 r., tj. zaniedbujący się $\mathrm{w}$ pracy naukowej bądź naruszający inne przepisy

${ }^{75}$ Zob. pkt 1 Rozporządzenia Ministra Nauki, Szkolnictwa Wyższego i Techniki z dnia 17 XI 1980 r. zmieniające rozporządzenie w sprawie studiów doktoranckich (Dz.U. Nr 26, poz. 109). 
obowiązujące w szkole wyższej, mógł być skreślony z listy doktorantów. O skreśleniu z listy orzekał minister. Podobnie warunki uzasadniające skreślenie z listy uczestników studiów doktoranckich (brak postępów w pracy naukowej, niewypełnianie obowiązków wynikających $\mathrm{z}$ rozporządzenia, z programu studiów i z regulaminu organizacyjnego) formułowało rozporządzenie z 1968 r. Przy czym tu o skreśleniu z listy uczestników studiów doktoranckich orzekała rada (wydziału, naukowa) po zapoznaniu się z opinią kierownika naukowego, kierownika studiów doktoranckich i komisji utworzonej dla sprawowania określonych czynności nadzoru. Od decyzji rady służyło odwołanie (w terminie czternastu dni od daty zawiadomienia), które ostatecznie rozstrzygał odpowiednio organ właściwy do utworzenia studiów doktoranckich. Od tych postanowień nie odbiegały zbytnio także dwa kolejne rozporządzenia - z 1976 i 1986 r. Pierwsze z nich oddzielało przesłanki prowadzące do skreślenia $\mathbf{z}$ listy uczestników studiów doktoranckich (brak wykazania postępów w pracy naukowej, a w szczególności niezaliczenie $\mathrm{w}$ przewidzianym terminie egzaminów lub niewykonanie w terminie określonych etapów pracy doktorskiej) od decyzji o wydaleniu ze studiów (z własnej winy niewywiązywanie się przez uczestnika studiów doktoranckich ze swoich obowiązków, w szczególności nieprzestrzeganie regulaminu organizacyjnego, nieprzykładanie się do otwarcia przewodu doktorskiego w terminie lub niewykonanie w terminie określonych etapów pracy doktorskiej). Drugie rozporządzenie (z 1986 r.) już takiego rozdziału przesłanek nie wprowadzało, co nie znaczy, że po nie nie sięgało w celu podjęcia decyzji o skreśleniu z listy uczestników studiów doktoranckich. Podstawę skreślenia stanowiło: niewykazanie dostatecznych postępów w pracy naukowej, a zwłaszcza niezaliczenie egzaminów $w$ terminach przewidzianych programem studiów; niewykonanie określonych w harmonogramie etapów pracy doktorskiej; niezłożenie rozprawy doktorskiej w terminie określonym programem studiów lub wykazanie niewłaściwej postawy obywatelskiej. Wobec braku zastrzeżenia, były to przesłanki rozłączne. Zaistnienie którejkolwiek z nich mogło prowadzić do skreślenia doktoranta (terminem "doktorant" prawodawca nie posługiwał się od czasu wejścia w życie rozporządzenia z 1968 r.) - co znamienne ${ }^{76}$ - z listy uczestni-

${ }^{76}$ Rozporządzenie Ministra Nauki i Szkolnictwa Wyższego z dnia 10 VII 1986 r. posługiwało się pojęciem "uczestnik studiów doktoranckich", po pojęcie "doktorant" sięgnęło jedynie dla określenia w $§ 14$ warunków postępowania w sprawie skreślenia z listy uczestników studiów doktoranckich. 
ków studiów doktoranckich. „Decyzję o skreśleniu doktoranta z listy uczestników studium" podejmował na wniosek kierownika studium kierownik właściwej jednostki organizacyjnej, informujący zarazem właściwego ministra lub sekretarza naukowego PAN. Od decyzji o skreśleniu przysługiwało prawo odwołania do ministra lub sekretarza PAN w terminie czternastu dni od dnia doręczenia.

\subsection{Wsparcie finansowe i socjalne doktorantów/ słuchaczy studiów doktoranckich}

Doktoranci/uczestnicy studiów doktoranckich korzystali ze wsparcia finansowego. Wsparcie to przybierało najczęściej formę stypendium, płatnego z góry. Oczywiście, jego wysokość ewoluowała. Z biegiem lat zmieniała się także oferta stypendialna (nie tylko odnoszona do doktorantów i uczestników studiów doktoranckich ${ }^{77}$ ) oraz warunki przyznawania środków, a wraz z otwarciem studiów doktoranckich dla osób pracujących - także podmiot przyznający i wypłacający stypendia.

Z mocy rozporządzenia z 1960 r. w okresie odbywania studiów doktoranckich (bez możliwości wykonywania jakichkolwiek stałych bądź okresowych zajęć zarobkowych ${ }^{78}$ ) doktorant otrzymywał stypendium w wysokości uposażenia netto starszego asystenta wraz

${ }^{77}$ Prawo do stypendiów służyło także osobom przygotowującym rozprawę doktorską poza studiami doktoranckimi na podstawie odrębnych przepisów, które przewidywały: (1) stypendium doktoranckie - Rozporządzenie Ministrów Szkolnictwa Wyższego, Zdrowia i Opieki Społecznej, Oświaty, Spraw Zagranicznych oraz Przewodniczącego Głównego Komitetu Kultury Fizycznej i Turystyki z dnia 30 IV 1960 r. w sprawie określenia warunków i trybu przyznawania stypendiów, udzielania płatnych urlopów oraz wysokości stypendiów dla osób, które pracują nad rozprawą doktorską bądź habilitacyjną w szkołach wyższych (Dz.U. Nr 28, poz. 160); (2) stypendium naukowe - Rozporządzenie Ministra Oświaty i Szkolnictwa Wyższego z dnia 15 II 1968 r. w sprawie zasad przyznawania stypendiów naukowych oraz praw i obowiązków osób przygotowujących rozprawę doktorską i habilitacyjną (Dz.U. Nr 6, poz. 39 ze zm.); Rozporządzenie Ministra Nauki, Szkolnictwa Wyższego i Techniki z dnia 29 I 1982 r. w sprawie zasad przyznawania stypendiów naukowych oraz praw i obowiązków osób pobierających te stypendia (Dz.U. Nr 5, poz. 43); Rozporządzenie Ministra Nauki i Szkolnictwa Wyższego z dnia 10 VII 1986 r. w sprawie studiów doktoranckich i stypendiów naukowych.

${ }^{78}$ Zob. \& 6 i 9 rozporządzenia z dnia 30 IV 1960 r. w sprawie zasad odbywania studiów doktoranckich w szkołach wyższych, praw i obowiązków doktorantów oraz wysokości stypendiów dla doktorantów. Zgodnie z $§ 9$ tegoż rozporządzenia pomocniczy pracownik nauki szkoły wyższej przyjęty na studia doktoranckie otrzymywał na okres studiów urlop bezpłatny. 
z przysługującymi dodatkami. Stypendium mogło być odpowiednio zwiększone, jeżeli doktorant odbywał studia w warunkach szczególnie szkodliwych dla zdrowia, uzasadniających przyznanie dodatku specjalnego w myśl przepisów o uposażeniu pracowników nauki. O zwiększeniu stypendium decydował minister. Doktorantowi przysługiwał także dodatek do stypendium na członków rodziny, w wysokości i na warunkach przewidzianych dla zasiłków rodzinnych dla pracujących. Skreślenie doktoranta $\mathrm{z}$ listy prowadziło do wstrzymania wypłaty stypendium z pierwszym dniem miesiąca następującego po wydaniu decyzji o skreśleniu.

Bardzo zbliżone warunki określały także kolejne rozporządzenia. Pierwsze z nich (z 1968 r.) przewidywało możliwość wypłacenia (ze środków finansowych jednostki prowadzącej studia doktoranckie) stypendium w wysokości nieprzekraczającej $2500 \mathrm{zł}$ miesięcznie, na podstawie oświadczenia uczestnika studium doktoranckiego, że nie pobiera stypendium z innego źródła lub wynagrodzenia z tytułu umowy o pracę. Zarazem założono, że "[p]rzyznanie stypendium powinno być w zasadzie uwarunkowane złożeniem zobowiązania, że po uzyskaniu stopnia naukowego doktora zainteresowany na wniosek organu (w szkole wyższej - rektor, w placówce PAN - kierownik placówki, $\mathrm{w}$ instytucie naukowo-badawczym oraz w samodzielnej placówce typu naukowo-dydaktycznego - dyrektor), podejmie na okres co najmniej trzech lat pracę $w$ instytucji naukowej wyznaczonej przez jednostkę przyznającą stypendium bądź zwróci stypendium" (\$ 11 ust. 3). Tymczasem pracownik naukowo-dydaktyczny i naukowo-badawczy przyjęty na studia doktoranckie na wniosek zatrudniającej go szkoły wyższej (placówki naukowej PAN lub instytutu naukowo-badawczego) otrzymywał na czas trwania studiów urlop bezpłatny oraz stypendium w wysokości odpowiadającej jego wynagrodzeniu netto pobieranemu bezpośrednio przed przyjęciem, jednakże w kwocie nie wyższej niż 3000 zł miesięcznie. Stypendium to przyznawała i wypłacała jednostka kierująca na studia. Stypendium nie podlegało podatkowi od wynagrodzeń. Skreślenie z listy uczestników studiów powodowało utratę stypendium, a co za tym idzie, wstrzymanie jego wypłaty z pierwszym dniem miesiąca następującego po wydaniu ostatecznej decyzji o skreśleniu.

Stypendyście oprócz stypendium przysługiwały także dodatki: (1) na członków rodziny w wysokości i na zasadach przewidzianych dla zasiłków rodzinnych dla pracujących oraz (2) ze względu na warunki szkodliwe dla zdrowia na zasadach obowiązujących w jednostce prowadzącej studia, 
o ile rodzaj zajęć na studiach uzasadniał przyznanie dodatku. W obu przypadkach dodatki wypłacała jednostka przyznająca stypendium.

Uczestnik studiów doktoranckich był także uprawniony do korzystania ze świadczeń społecznych zakładów służby zdrowia oraz ulg przy przejazdach kolejowych i środkami komunikacji miejskiej w zakresie przysługującym pracownikom jednostki prowadzącej studia doktoranckie. Stypendysta nie mógł wykonywać żadnych zajęć zarobkowych na podstawie umowy o pracę. Wykonywanie pracy dodatkowej na podstawie umowy zlecenia lub umowy o dzieło wymagało każdorazowo zgody kierownika jednostki prowadzącej studia.

Rozporządzenie z 1968 r., mimo wprowadzonej możliwości przyjęcia na studia doktoranckie także osób łączących ich odbywanie z pracą zarobkowa, prawo do uzyskania stypendium zawężało jedynie do pracowników naukowo-dydaktycznych i naukowo-badawczych korzystających z urlopu bezpłatnego. Dopiero rok 1971 przyniósł w tym zakresie zmiany. Uchwała nr 156 Rady Ministrów z tego roku przewidywała możliwość przyznania i wypłaty uczestnikowi studiów doktoranckich dla pracujących ${ }^{79}$, na jego wniosek ${ }^{80}$, stypendium naukowego (a nie stypendium ${ }^{81}$ ) w wysokości 1000 zł miesięcznie na łączny okres dwunastu miesięcy (od połowy lipca 1982 r. - 1800 zł na okres osiemnastu miesięcy ${ }^{82}$ w ciągu trwania studiów. W szczególnych przypadkach

${ }^{79} \mathrm{Na}$ źródła finansowania stypendiów naukowych wypłacanych przez zakłady pracy pracownikom skierowanym na studia doktoranckie dla pracujących wskazywało Zarządzenie Ministra Finansów z dnia 9 III 1972 r. w sprawie zasad finansowania i zwrotu stypendiów naukowych wypłacanych uczestnikom studiów doktoranckich dla pracujących (M.P. Nr 22, poz. 129).

${ }^{80}$ Wniosek wymagał załączenia: informacji jednostki prowadzącej studia o przebiegu i wynikach studiów osoby ubiegającej się o stypendium oraz oświadczenia uczestnika studiów o niewykonywaniu lub jego zobowiązaniu do zaprzestania wykonywanych poza głównym miejscem pracy dodatkowych zajęć zarobkowych w okresie pobierania stypendium.

${ }^{81}$ Przyznawanie uczestnikom studiów doktoranckich dla pracujących stypendium naukowego (a nie stypendium) uzasadniało wyłączenie wobec nich przepisów rozporządzeń $(1968,1976,1986)$ w zakresie normującym zasady i warunki przyznawania stypendium uczestnikom studiów doktoranckich niepracującym lub korzystającym z urlopu bezpłatnego. $Z$ drugiej strony nazwa ta była myląca. Możliwość przyznania stypendium naukowego rezerwowano od 1968 r. wyłącznie dla osób przygotowujących rozprawę doktorską poza studiami doktoranckimi (Rozporządzenie Ministra Oświaty i Szkolnictwa Wyższego z dnia 15 II 1968 r.).

82 Zob. § 1 pkt 1 Uchwały nr 140 Rady Ministrów z dnia 5 VII 1982 r. zmieniającej uchwałę w sprawie kierowania pracowników na studia doktoranckie dla pracujacych oraz w sprawie ulg i świadczeń przysługujących tym pracownikom (M.P. Nr 17, poz. 140). 
stypendium to mogło być przyznane na dalszy okres, nie dłuższy jednak niż sześć miesięcy. Prawo pobierania stypendium obwarowano zakazem wykonywania w tym czasie, poza głównym miejscem pracy, dodatkowych stałych zajęć zarobkowych. Wykonywanie pracy dodatkowej na podstawie umowy zlecenia lub umowy o dzieło wymagało każdorazowej zgody kierownika jednostki prowadzącej studia i kierownika zakładu pracy. Stypendium przyznawał i wypłacał, w ramach posiadanych środków na ten cel, zakład pracy kierujący pracownika na studia. Przyznanie stypendium mogło nastąpić także z inicjatywy ministra (kierownika urzędu centralnego), któremu podlegał dany zakład pracy. Zakład pracy mógł cofnąć stypendium, jeżeli stypendysta: został skreślony z listy uczestników studiów bądź nie wykazywał dostatecznych postępów w nauce albo wykonywał bez zezwolenia dodatkowe zajęcia zarobkowe. Stypendium podlegało zwrotowi w całości w razie: niespełnienia przez stypendystę zobowiązania podjęcia pracy po ukończeniu studiów w zakładzie pracy przez okres co najmniej trzech lat na stanowisku odpowiadającym jego kwalifikacjom lub w razie skreślenia stypendysty z jego winy z listy uczestników studiów. Zwolnienie od obowiązku zwrotu stypendium mogło nastąpić w trybie i na zasadach określonych w odrębnych przepisach ${ }^{83}$.

Ponadto pracownik skierowany na studia od zakładu pracy otrzymywał: (1) płatny urlop szkoleniowy w wymiarze do dwudziestu ośmiu dni na przygotowanie się do egzaminów lub przeprowadzenie obrony doktorskiej. Urlop ten mógł być przez zakład pracy udzielony jednorazowo lub w częściach, w wymiarze określonym przez jednostkę prowadzącą studia; (2) ryczałt na pokrycie poniesionych kosztów przejazdów i noclegów (jeżeli siedziba studiów znajdowała się poza siedzibą zakładu pracy) w kwocie do 600 zł miesięcznie ${ }^{84}$; ponadto (3) pokrycie kosztów noclegów. Prawa te, podobnie jak prawo do stypendium naukowego, nie przysługiwały każdemu. Nie mogli z nich skorzystać: pracownicy w okresie odbywania stażu naukowego lub zawodowego w czasie studiów doktoranckich, jeżeli $\mathrm{w}$ tym okresie korzystali $\mathrm{z}$ uprawnień wynikających z uchwały nr 97 Rady Ministrów z 1967 r. ${ }^{85}$, a także ci,

${ }^{83}$ Zob. § 7 Uchwały nr 294 Rady Ministrów z dnia 23 IX 1968 r. w sprawie fundowanych stypendiów doktoranckich (M.P. Nr 41, poz. 288).

${ }^{84}$ Od 1982 r. mocą uchwały nr 140 Rady Ministrów z dnia 5 VII 1982 r. ryczałt ten wynosił $1500 \mathrm{zł} \mathrm{miesięcznie.}$

${ }^{85}$ Chodzi tu o Uchwałę nr 97 Rady Ministrów z dnia 5 V 1967 r. w sprawie krajowych staży naukowych i zawodowych dla pracowników naukowo-dydaktycznych 
którym nie przysługiwało zwolnienie z pracy na zajęcia obowiązkowe $\mathrm{w}$ wymiarze do czternastu godzin miesięcznie oraz płatny urlop szkoleniowy w wymiarze do dwudziestu ośmiu dni na przygotowanie się do egzaminów lub przeprowadzenie obrony pracy doktorskiej w trybie i na zasadach określonych Zarządzeniem nr 66 Prezesa Rady Ministrów z dnia 29 marca 1954 r. w sprawie urlopów pracowniczych na dokończenie nauk ${ }^{86}$, jeśli do nich znajdowały zastosowanie przepisy rozporządzenia Rady Ministrów z 1967 r. ${ }^{87}$

W myśl rozporządzenia z 1976 r. w okresie odbywania studiów doktoranckich jego uczestnikowi przysługiwało prawo do stypendium w wysokości nieprzekraczającej 3000 zł miesięcznie (od 1980 r. - 3600 zł na pierwszym roku studiów, 4200 zł na dalszych latach), przy zachowaniu warunków podanych powyżej ${ }^{88}, \mathrm{z}$ równoczesnym zastrzeżeniem, że stypendysta po ukończeniu studiów doktoranckich podejmie, na wniosek kierownika jednostki prowadzącej studia doktoranckie, na okres co najmniej trzech lat, pracę w naukowej instytucji wyznaczonej przez jednostkę przyznającą stypendium bądź zwróci stypendium. W nieco zwiększonej wysokości, do 3500 zł (od 1980 r. - 4100 zł miesięcznie na pierwszym roku studiów, $4700 \mathrm{zł}$ na dalszych latach ${ }^{89}$ ), miał otrzymywać stypendium $\mathrm{w}$ okresie trwania studiów doktoranckich nauczyciel akademicki, pracownik naukowo-badawczy, dyplomowany pracownik dokumentacji naukowej oraz bibliotekarz dyplomowany - przyjęty na studia doktoranckie na wniosek zatrudniającego go zakładu pracy, w czasie udzielonego mu bezpłatnego urlopu. Od 1983 r. tej samej grupie zawodowej, przy założeniu otrzymania urlopu bezpłatnego, służyło prawo uzyskania, na czas trwania studiów doktoranckich, stypendium w wysokości 9000 zł miesięcznie. Dla pozostałych uczestników studiów doktoranckich kwoty stypendiów ustalono na niższym poziomie 7000 zł miesięcznie na I roku studiów i 8300 zł miesięcznie na dalszych

i naukowo-badawczych oraz innych pracowników zatrudnionych w jednostkach organizacyjnych gospodarki narodowej (M.P. Nr 34, poz. 158).

${ }^{86}$ M.P. Nr A-31, poz. 455.

${ }^{87}$ Chodzi tu o Rozporządzenie Rady Ministrów z dnia 25 VII 1967 r. w sprawie warunków zatrudniania pracowników naukowo-badawczych (Dz.U. Nr 32, poz. 157 ze zm.).

${ }^{88}$ Stypendysta nie mógł wykonywać żadnych zajęć zarobkowych na podstawie umowy o pracę, wykonywanie pracy na podstawie umowy zlecenia lub umowy o dzieło wymagało zaś każdorazowo zgody kierownika jednostki prowadzącej studia doktoranckie.

${ }^{89}$ Rozporządzenie Ministra Nauki, Szkolnictwa Wyższego i Techniki z dnia 17 XI 1980 r. zmieniające rozporządzenie w sprawie studiów doktoranckich. 
latach studiów ${ }^{90}$. Kwoty stypendiów podwyższono od 1 stycznia $1984 \mathrm{r} .^{91}$ o 1000 zł. Stypendium wypłacano również (co było rozwiązaniem nowym) w okresie niezdolności do uczestniczenia w studiach wskutek choroby, sprawowania opieki nad dzieckiem lub innym chorym członkiem rodziny albo z tytułu korzystania z urlopu macierzyńskiego przez okres odpowiadający okresowi wypłaty zasiłków z ubezpieczenia społecznego. Tak jak pod rządami rozporządzenia z 1968 r. uczestnikowi studiów doktoranckich przysługiwały także dodatki: na członków rodziny i za pracę $\mathrm{w}$ warunkach szkodliwych dla zdrowia oraz świadczenia społecznych zakładów służby zdrowia w zakresie przysługującym pracownikom jednostki prowadzącej studia doktoranckie.

Tego stanu rzeczy zbytnio nie zmieniło rozporządzenie Ministra Nauki, Szkolnictwa Wyższego i Techniki z dnia 10 lipca 1986 r., aczkolwiek odstąpiło od kwotowego określenia wysokości stypendiów. I tak, uczestnicy studium doktoranckiego otrzymywali stypendium w wysokości odpowiadającej: na I roku - średniemu wynagrodzeniu zasadniczemu w szkole wyższej; na II roku i dalszych latach - średniemu wynagrodzeniu zasadniczemu starszego asystenta w szkole wyższej ${ }^{92}$. Stypendium przyznawała i wypłacała jednostka organizacyjna prowadząca studia doktoranckie. Gdy uczestnik studium doktoranckiego ukończył je w terminie krótszym niż cztery lata oraz uzyskał wyróżniającą ocenę pracy doktorskiej, mógł otrzymać premię w wysokości nieprzekraczającej różnicy między kwotą stypendium planowanego a faktycznie pobranego. Decyzję w tym zakresie podejmował właściwy minister lub sekretarz naukowy PAN na wniosek kierownika jednostki organizacyjnej prowadzącej studium. Przyznanie stypendium nie stało na przeszkodzie przyznaniu uczestnikowi studiów doktoranckich, z którym zakład pracy zawarł przed przystąpieniem do egzaminów wstępnych umowę określającą wzajemne prawa i obowiązki (zakładu pracy i pracownika), dodatkowego świadczenia, w ramach posiadania

${ }^{90}$ Zob. Rozporządzenie Ministra Nauki, Szkolnictwa Wyższego i Techniki z dnia 22 II 1983 r. zmieniające rozporządzenie w sprawie studiów doktoranckich (Dz.U. Nr 10, poz. 53).

${ }^{91}$ Rozporządzenie Ministra, Nauki, Szkolnictwa Wyższego i Techniki z dnia 9 IV 1984 r. zmieniające rozporządzenie w sprawie studiów doktoranckich (Dz.U. Nr 24, poz. 123).

${ }^{92}$ Od 1 VIII 1989 r. wysokość stypendiów podwyższono o dodatek pieniężny z tytułu wzrostu cen podstawowych artykułów żywnościowych (Rozporządzenie Ministra Edukacji Narodowej z dnia 29 VII 1989 r. zmieniające rozporządzenie w sprawie studiów doktoranckich i stypendiów naukowych (Dz.U. Nr 47, poz. 257). 
na ten cel środków, a zwłaszcza pokrycia kosztów podręczników, literatury specjalistycznej, maszynopisu rozprawy doktorskiej lub innych wynikających z prowadzonych badań naukowych.

Uczestnikom studiów doktoranckich odbywającym studia poza miejscem stałego zamieszkania przysługiwało nadto prawo do odpłatnego zakwaterowania w hotelu asystenckim lub domu studenckim (po raz pierwszy przyjęte rozwiązanie). W razie niemożności spełnienia tego warunku przez jednostkę organizacyjną prowadząca studia doktoranckie zapewniono przyznanie ryczałtu na wynajęcie lokalu mieszkalnego w wysokości różnicy między kosztem utrzymania miejsca w hotelu dla nauczycieli akademickich lub domu studenckim a wysokością odpłatności za to miejsce.

Rozporządzenie z 1986 r. przyjęło generalną zasadę, że uczestnikom studiów doktoranckich przysługują uprawnienia pracownicze wynikające ze stosunku pracy takie jak pracownikom jednostki prowadzącej studia doktoranckie, z wyjątkiem prawa do: (1) wynagrodzenia, (2) korzystania z zakładowego funduszu nagród i nagród wypłacanych z innych tytułów, (3) świadczeń pracowniczych związanych z daną branżą, (4) urlopu dla celów naukowych, artystycznych lub kształcenia zawodowego, urlopu dla poratowania zdrowia i urlopu wychowawczego. Okres studiów doktoranckich zaliczano do okresu zatrudnienia, od którego zależały uprawnienia pracownicze, z pewnym jednak zastrzeżeniem. Uprawnieniem tym objęto tylko te osoby: (1) którym udzielono urlopu bezpłatnego na czas trwania studiów doktoranckich i które bezpośrednio po jego upływie podjęły pracę, (2) z którymi rozwiązano stosunek pracy po przyjęciu na studia doktoranckie i które podjęły pracę nie później niż w ciągu trzech miesięcy od daty ukończenia tych studiów.

\section{Podsumowanie}

Prowadzenie w Polsce Ludowej aspirantury naukowej służyło uzyskaniu stopnia naukowego kandydata nauk. Prowadzenie w Polskiej Rzeczypospolitej Ludowej (od 1958 r.) studiów doktoranckich pozwalało z kolei na uzyskanie stopnia naukowego doktora. I choć w obu wariantach rozwiązań prawnych chodziło o nabycie niższego stopnia naukowego, drogi prowadzące do jego uzyskania nie były porównywalne. Różnice sprowadzały się nie tylko do formuły prowadzenia aspirantury 
naukowej i studiów doktoranckich, celów i dostępu do studiów (aspiranckich, doktoranckich), ale także do zasad organizacji i warunków ich przebiegu.

Ustawa z 1958 r., choć nie przyniosła stabilności rozwiązań w zakresie nadawania niższych stopni naukowych, bez wątpienia zapoczątkowała proces ważny - prowadzenie studiów doktoranckich. Ocena prawnych rozwiązań do nich odnoszonych dowiodła także ich ważności dla kształcenia kadry naukowej, a zarazem potrzeb gospodarki narodowej. I choć od tej tendencji nie odstąpiono w latach następnych, prawem przewidziane warunki tworzenia studiów doktoranckich, cele i formy uzasadniające ich prowadzenie oraz programy studiów ewoluowały. O ile zmiany w odniesieniu do aspirantury naukowej nie były znaczące, o tyle wprowadzane $w$ latach późniejszych rozwiązania dotyczące studiów doktoranckich były dowodem przemian dalej idących, nie tylko ze względu na podstawę prawną ich tworzenia i prowadzenia. Wraz ze zmianami polityczno-ustrojowymi zmieniał się bowiem sposób postrzegania szkół wyższych (jako mniej lub bardziej autonomicznych) i odpowiednio do tego ich prawa do prowadzenia studiów doktoranckich. W konsekwencji zmieniały się także zakresy praw i obowiązków podmiotów współuczestniczących w procesie prowadzącym do nadania stopnia naukowego doktora. Zakres wprowadzanych zmian w szczególności dotyczył kompetencji właściwych ministrów (sekretarzy naukowych PAN) oraz władz uczelni i władz wydziałowych (dyrektorów instytutów, placówek naukowo-badawczych), ale także opiekunów naukowych sprawujących bezpośrednią pieczę nad doktorantami/ uczestnikami studiów doktoranckich. Zmianom podlegały także prawa doktorantów/uczestników studiów doktoranckich, stosownie do przyjętej formuły studiów (dla "niezatrudnionych”, „korzystających z urlopu bezpłatnego", „pracujących", „z oderwaniem od pracy”).

Gros ówcześnie przyjmowanych rozwiązań bez wątpienia odpowiadało zapotrzebowaniu "profilowania” kształcenia, poprzez zmienne w czasie formułowanie celów i warunków dostępu do studiów prowadzących do uzyskania niższego stopnia naukowego oraz zasad ich organizacji. W dobie współczesnych rozwiązań, i na ich tle, ogólna ocena unormowań z okresu objętego analizą nie wypada bezwzględnie źle, poza tymi, które powielając wzorce radzieckiej aspirantury naukowej, odstąiły od polskiej tradycji, jak i tymi z lat późniejszych, które zdecydowanie preferowały system scentralizowanych studiów doktoranckich, z różnym natężeniem, stosownie do okresu przyjmowanych reform, 
marginalizującymi autonomię szkół wyższych i instytutów naukowych oraz z różnym natężeniem ideologizującymi programy studiów. Ówczesne studia doktoranckie bezsprzecznie były zhierarchizowane i przeregulowane, co służyło kontrolowaniu przez państwo cyklu kształcenia, a ponadto - przez podporządkowanie ideologii socjalistycznych przemian - pozwalało na kontrolę badań naukowych nie tylko uczestników studiów doktoranckich.

Na ich tle współcześnie (2011-2014) przyjęte rozwiązania w odniesieniu do studiów doktoranckich z pewnością wypadają lepiej. Przede wszystkim odstąpiono od upolitycznienia tych studiów, zelżały także centralistyczne tendencje do kierowania przez państwo szkołami wyższymi (a tym samym również życiem akademickim i naukowym). Sprawowanie nadzoru merytorycznego nad studiami doktoranckimi należy do organów szkół wyższych i jednostek naukowych, co jednak nowym uregulowaniem nie jest. Zbliżone rozwiązania wdrożono już rozporządzeniami z 1968 i 1976 r. i tak jak wtedy rozbudowano system kontroli wewnętrznej i zewnętrznej. Począwszy od 1968 r., kierowanie studiami doktoranckimi należy do kierowników tych studiów, których jak dawniej obarczano obowiązkiem ustawicznie składanych sprawozdań. Władzy centralnej pozostawiono wpływ na proces tworzenia i określania zasad prowadzenia studiów doktoranckich. Ministrowi właściwemu do spraw szkolnictwa wyższego powierzono określanie ramowego programu kształcenia dla studiów doktoranckich. Przy tym, począwszy od 2011 r., główne zmiany skoncentrowano na wprowadzeniu: przyporządkowanych określonym obszarom wiedzy (1) efektów kształcenia dla studiów doktoranckich, odtąd uznawanych za studia trzeciego stopnia, oraz (2) punktów ECTS, w sposób nie dość jasno skorelowanych z programami studiów doktoranckich, przy przyjęciu ich różnych wartości potrzebnych dla zakończenia studiów (w 2011 r. - od 45 do 60, od 2013 r. - od 30 do 45 punktów ${ }^{93}$ ) i dla każdej grupy proponowanych nimi modułów, $\mathrm{w}$ istocie przy nieznacznie zmienionych $\mathrm{w}$ tym okresie elementach wyznaczających zakres programu studiów doktoranckich.

Bez wątpienia słabością współczesnych rozwiązań jest brak przemyślanej koncepcji studiów doktoranckich. Studia te w kształcie

${ }^{93}$ Zob. § 4 Rozporządzenia Ministra Nauki i Szkolnictwa Wyższego z dnia 1 IX 2011 r. w sprawie kształcenia na studiach doktoranckich w uczelniach i jednostkach naukowych (Dz.U. Nr 196, poz. 1169) oraz § 1 pkt 1 Rozporządzenia Ministra Nauki i Szkolnictwa Wyższego z dnia 1 VII 2013 r. zmieniające rozporządzenie w sprawie kształcenia na studiach doktoranckich w uczelniach i jednostkach naukowych (Dz.U. poz. 841). 
określonym w 2011 r., i w 2013 r. dookreślonym, mają być skoncentrowane na realizacji programów ${ }^{94}$ przygotowujących - najogólniej rzecz ujmując - do pracy o charakterze badawczym lub badawczo-rozwojowym, zdobycia umiejętności związanych z metodyką i metodologią prowadzenia badań naukowych, od 2013 r. także do wykonywania zawodu nauczyciela akademickiego. Nie jest to rozwiązanie nowe. Bardzo do niego zbliżone wprowadzono już w 1952 r. dla aspirantury naukowej i w 1986 r. dla studiów doktoranckich. Dla realizacji programów w zakresie powyżej podanym nie ma większego znaczenia forma studiów (stacjonarne - niestacjonarne), formuła programowa jest dla obu form tożsama ${ }^{95}$. Ustawa Prawo o szkolnictwie wyższym w art. 195 ust. 5 stanowi jedynie, że „[o]rganizacja niestacjonarnych studiów doktoranckich zapewnia możliwość odbywania studiów doktoranckich osobom zatrudnionym w ramach stosunku pracy". W istocie więc celem studiów trzeciego stopnia jest przygotowanie ich uczestników do pracy badawczej i dydaktycznej (i to bez względu na formę studiów), jakże różnego od celów $z$ lat wcześniejszych, kształtowanych i adresowanych do aspirantów pracujących zawodowo, później uczestników studiów doktoranckich dla pracujących lub z oderwaniem od pracy. Aktualnie obowiązujące rozwiązania bezsprzecznie takiego założenia nie przyjmują. Proponują natomiast możliwość korzystania z prawa do grantów (zewnętrznych i wewnętrznych) dla sfinansowania prowadzonych badań naukowych, bez względu na to, jakim celom mają one służyć

${ }^{94}$ Zob. § 5 rozporządzenia Ministra Nauki i Szkolnictwa Wyższego z dnia 1 IX 2011 r., który brzmiał: „Realizacja programu studiów doktoranckich przygotowuje do pracy o charakterze badawczym lub badawczo-rozwojowym, a w szczególności prowadzi do osiągnięcia efektów kształcenia w zakresie: 1) wiedzy na zaawansowanym poziomie, o charakterze podstawowym dla dziedziny związanej z obszarem prowadzonych badań naukowych, obejmującej najnowsze osiągnięcia nauki lub sztuki oraz o charakterze szczegółowym, odpowiadające obszarowi prowadzonych badań naukowych, obejmującej najnowsze osiągnięcia nauki lub sztuki; 2) umiejętności związanych z metodyką i metodologią prowadzenia badań naukowych; 3) kompetencji społecznych odnoszących się do działalności naukowo-badawczej i społecznej roli uczonego lub artysty". Powyższą treść zmieniono rozporządzeniem Ministra Nauki i Szkolnictwa Wyższego z dnia 1 VII 2013 r. przez dodanie do $\S 5$ ust. 2 w brzmieniu: „2. Realizacja programu studiów doktoranckich w uczelni przygotowuje do wykonywania zawodu nauczyciela akademickiego i prowadzi do osiągnięcia efektów kształcenia w zakresie umiejętności związanych z metodyką i techniką prowadzenia zajęć dydaktycznych, w tym z wykorzystaniem nowych technologii w kształceniu studentów".

${ }^{95}$ Wymagania określone w $§$ 3-6 rozporządzenia z dnia 1 IX 2011 r. (dotyczące realizacji programu studiów doktoranckich) stosuje się w procesie kształcenia odbywanym na stacjonarnych i niestacjonarnych studiach doktoranckich. 
(nauce czy także państwu i gospodarce). Wszystko to sprawia, że obecne unormowania są etapem początkowym w poszukiwaniu pożądanego modelu studiów doktoranckich.

W takim ujęciu prawne regulacje kształtujące studia doktoranckie dla osób odbywających je w formie niestacjonarnej w żadnym razie nie zadowalają. Uwagę tę wzmacnia niebagatelna kwestia braku wsparcia stypendialnego tej grupy doktorantów (niejednokrotnie osiągających założone programem studiów doktoranckich wyniki wyższe aniżeli doktoranci stacjonarni), jednocześnie obciążonych obowiązkiem uiszczania opłaty za studia ${ }^{96}$. Doktoranci studiów niestacjonarnych nie mają prawa do stypendium doktoranckiego, a tym samym i do jego zwiększenia w ramach dotacji projakościowej. Aspiranci aspirantury naukowej dla pracujących zawodowo, a także uczestnicy studiów doktoranckich łączący je z pracą zawodową otrzymywali w latach minionych stypendia.

Nie bez znaczenia i zasługujące na krytyczną ocenę w tym zakresie są też rozwiązania dające doktorantom stacjonarnym prawo ubiegania się w tym samym roku akademickim o stypendium doktoranckie ${ }^{97}$ i stypendia z innych źródeł finansowanych ze środków publicznych (kumulacja stypendiów możliwa do osiągnięcia przez tego samego doktoranta), bez uwzględniania przy ustalaniu prawa do stypendium ich dochodów osiąganych z tytułu zatrudnienia. W odróżnieniu od okresu sprzed $2011 \mathrm{r}^{98}$ wyłania się zatem obraz następujący: $\mathrm{z}$ jednej strony nieodpłatne studia doktoranckie stacjonarne $\mathrm{z}$ możliwością jednoczesnego zatrudnienia i zachowanym prawem do stypendium doktoranckiego, $\mathrm{z}$ drugiej - płatne studia doktoranckie niestacjonarne z możliwością zatrudnienia, bez prawa do takiego stypendium, w obu przypadkach służące przygotowaniu młodej kadry naukowej i dydaktycznej.

${ }^{96}$ Od 2011 r. opłata za niestacjonarne studia doktoranckie jest ustalana przez szkoły wyższe i jest przez nie pobierana. Ustawa z dnia 27 VII 2005 r. Prawo o szkolnictwie wyższym (tekst jedn. Dz.U. 2014, poz. 572) takiego imperatywu nie formułuje. Stanowi tylko, że "[n]iestacjonarne studia doktoranckie mogą być odpłatne" (art. 195 ust. 9).

${ }^{97}$ Zgodnie z art. 200 ust. 1 Ustawy z dnia 27 VII 2005 r. Prawo o szkolnictwie wyższym „[u ] czestnik stacjonarnych studiów doktoranckich może otrzymywać stypendium doktoranckie. Wysokość opłat [...] ustala rektor uczelni lub dyrektor jednostki naukowej".

${ }_{98}$ Zob. $\S 13$ ust. 2 Rozporządzenia Ministra Nauki i Szkolnictwa Wyższego z dnia 19 XII 2006 r. w sprawie studiów doktoranckich prowadzonych przez jednostki organizacyjne uczelni (Dz.U. Nr 1, poz. 3 ze zm.), na mocy którego od doktoranta wykonującego pracę zawodową wymagano załączenia do wniosku o stypendium oświadczenia o wymiarze czasu pracy i wysokości dochodów uzyskiwanych w związku z wykonywaniem tej pracy. 


\section{ACADEMIC DEGREES IN THE POLISH PEOPLE'S REPUBLIC. PART 2. ORGANISATION OF POST-GRADUATE STUDIES (ASPIRANTURA) AND DOCTORAL STUDIES}

\section{Sum mary}

Between 1952-1990 a lower academic degree could be earned in a number of ways, two of which were post graduate studies (aspirantura) and doctoral studies. The organisation of post graduate studies followed the Soviet solution available from 1951. Participants obtained a title of a science candidate. Doctoral studies, implemented in 1958, allowed participants to earn a title of a doctor. The two ways discussed in the paper differed significantly but shared a common feature: the solutions which they implemented served firstly, to recruit candidates ready to engage in research and academic teaching; secondly, to ensure the social and economic society availability of professionals with qualifications exceeding the knowledge gained at an institution of higher education; thirdly, to provide institutional scientific guardianship to doctoral students working on their dissertations; fourthly, to realise the educational programme prepared for doctoral students who were adequately prepared for post graduate studies; and fifthly, to precisely define the status of scientific researchers working on scientific dissertations and to establish the principles upon which they received financial and social assistance.

In both cases, education leading to a scientific degree differed in stability. While those regarding aspirantura were largely constant and durable, doctoral studies lacked this durability. The elements which were taken into consideration when examining the latter form of $\mathrm{PhD}$ studies included in particular: determination of the purpose of offering doctoral studies, forms in which doctoral studies were conducted (both for employed and non-employed candidates), recruitment and admission requirements, and the conditions in which the course was conducted. The whole process was also found to be subject to the changing scope of rights and duties of doctoral students, their tutors as well as supervisory bodies responsible for doctoral studies.

Keywords: scientific aspirantura - doctoral studies - recruitment and organisation of doctoral studies between 1951-1990 